\title{
Adsorptive Removal of Acid Blue 80 Dye from Aqueous Solutions by $\mathrm{Cu}_{-} \mathrm{TiO}_{2}$
}

\author{
Ingrid Johanna Puentes-Cárdenas, ${ }^{1}$ Griselda Ma. Chávez-Camarillo, ${ }^{1}$ \\ César Mateo Flores-Ortiz, ${ }^{2}$ María del Carmen Cristiani-Urbina, ${ }^{3}$ \\ Alma Rosa Netzahuatl-Muñoz, ${ }^{4}$ Juan Carlos Salcedo-Reyes, ${ }^{5}$ \\ Aura Marina Pedroza-Rodríguez, ${ }^{5}$ and Eliseo Cristiani-Urbina ${ }^{1}$ \\ ${ }^{1}$ Escuela Nacional de Ciencias Biológicas, Instituto Politécnico Nacional, Prolongación de Carpio y Plan de Ayala s/n, \\ Colonia Santo Tomás, 11340 México, DF, Mexico \\ ${ }^{2}$ Facultad de Estudios Superiores Iztacala, Universidad Nacional Autónoma de México, Avenida de los Barrios 1, \\ Los Reyes Iztacala, 54090 Tlalnepantla, MEX, Mexico \\ ${ }^{3}$ Universidad Autónoma de Chiapas, Boulevard Belisario Domínguez, Kilómetro 1081, s/n, 29000 Tuxtla Gutiérrez, CHIS, Mexico \\ ${ }^{4}$ Universidad Politécnica de Tlaxcala, Avenida Universidad Politécnica No. 1, San Pedro Xalcaltzinco, 90180 Tepeyanco, TLAX, Mexico \\ ${ }^{5}$ Facultad de Ciencias, Pontificia Universidad Javeriana, Carrera 7 No. 40-62, Bogotá D.C. 11001000, Colombia
}

Correspondence should be addressed to Eliseo Cristiani-Urbina; ecristianiu@yahoo.com.mx

Received 21 September 2015; Accepted 8 December 2015

Academic Editor: Pantaleo D. Cozzoli

Copyright (C) 2016 Ingrid Johanna Puentes-Cárdenas et al. This is an open access article distributed under the Creative Commons Attribution License, which permits unrestricted use, distribution, and reproduction in any medium, provided the original work is properly cited.

\begin{abstract}
The adsorption performance of a $\mathrm{Cu}-\mathrm{TiO}_{2}$ composite for removing acid blue 80 (AB80) dye from aqueous solutions was investigated in terms of kinetics, equilibrium, and thermodynamics. The effect of operating variables, such as solution $\mathrm{pH}$, initial dye concentration, contact time, and temperature, on AB80 adsorption was studied in batch experiments. AB80 adsorption increased with increasing contact time, initial dye concentration, and temperature and with decreasing solution pH. Modeling of adsorption kinetics showed good agreement of experimental data with the pseudo-second-order kinetics model. The experimental equilibrium data for AB80 adsorption were evaluated for compliance with different two-parameter, three-parameter, and four-parameter isotherm models. The Langmuir isotherm model best described the AB80 adsorption equilibrium data. The thermodynamic data revealed that the $\mathrm{AB} 80$ adsorption process was endothermic and nonspontaneous. Kinetics, equilibrium, and thermodynamic results indicate that $\mathrm{Cu}-\mathrm{TiO}_{2}$ adsorbs $\mathrm{AB} 80$ by a chemical sorption reaction.
\end{abstract}

\section{Introduction}

Synthetic dyes are extensively used in many industries, such as textiles, printing, paper, leather, rubber, food, cosmetics, plastics, pharmaceuticals, and photography [1].

Large quantities of industrial wastewater containing synthetic dyes are directly discharged into water bodies without treatment, which has caused serious pollution problems in many areas [2] and has been a cause of concern because of the potential health hazards of dyes [3]. Dye-colored wastewater also affects aesthetics and water transparency, as well as the natural equilibrium of aquatic systems resulting from reduced oxygenation of the water bodies, and low photosynthetic activity and viability of aquatic plants due to water coloration [4]. Therefore, the removal of synthetic dyes from contaminated water and wastewater is presently recognized to be essential to protecting aquatic and terrestrial environments and public health and well-being [3].

However, dye-polluted wastewater is among the most difficult industrial wastewater types to treat [5] because most of the synthetic dyes are recalcitrant organic molecules that are highly resistant to microbial degradation, extremely soluble in water, and resistant to heat, light, and oxidizing agents $[3,6]$. 
Among several treatment technologies available for dye removal from aqueous solutions, photocatalytic degradation processes have been found to be efficient technologies for the removal of organic dyes from wastewater [7-10]. In this context, titanium dioxide $\left(\mathrm{TiO}_{2}\right)$ has become one of the most promising photocatalysts for complete mineralization of many toxic and nonbiodegradable organic compounds due to its chemical-biological inertness, availability, durability, high photocatalytic activity, long-term stability against photochemical corrosion, high refractive index, excellent optical transmittance, ecofriendly nature, and cost effectiveness [11, 12]. However, to improve the photocatalytic activity of $\mathrm{TiO}_{2}$ and to extend its photoresponse capacity to the visible region, $\mathrm{TiO}_{2}$ has been doped with various transition metal ions [12, 13]. A promising $\mathrm{TiO}_{2}$ dopant is divalent copper [Cu(II)], a relatively abundant metal with low cost that may extend the light absorption to the visible region, modify the $\mathrm{TiO}_{2}$ valence band spectrum, and improve photocatalytic activity [14, 15].

A crucial and primary stage in photocatalytic processes is the adsorption of reacting substances onto the surface of the photocatalysts $[16,17]$. It is well known that photodegradation of organic molecules is closely related to their adsorption on the photocatalyst surface, thus facilitating electron injection from the adsorbed excited molecules to the photocatalyst $[11,18]$. Therefore, prior adsorption of organic substances onto the photocatalysts' surface is indispensable for achieving higher photodegradation efficiencies and rates in heterogeneous photocatalysis $[11,14,18,19]$. Similarly, understanding the effect of environmental parameters (e.g., contact time, solution $\mathrm{pH}$, initial adsorbate concentration, and temperature) on adsorption, as well as the mechanism of adsorption, is essential for understanding the performance of photocatalysts and the kinetics of the photocatalytic reaction and for developing optimized photocatalytic processes [20]. In this context, the mechanism of adsorption can be elucidated from adsorption kinetics, isotherm, and thermodynamic studies.

Hence, the present study assesses the adsorption capacity of a new $\mathrm{Cu}-\mathrm{TiO}_{2}$ photocatalyst for acid blue 80 (AB80) dye, which is an anionic anthraquinone dye widely used in detergents, textiles (e.g., wool and nylon), disinfectants, sterilants, sanitation, cosmetics, pesticides, and preservative applications. AB80 is highly resistant to degradation due to its fused aromatic structure $[5,21]$ and has been identified by the Canadian Ministers of the Environment and Health as a priority substance because of its potential environmental persistence, bioaccumulation, and toxicity to aquatic organisms [21].

In the present work, a $\mathrm{Cu}-\mathrm{TiO}_{2}$ composite was synthesized and characterized by X-ray diffraction (XRD), field emission scanning electron microscopy (FE-SEM), energy dispersive X-ray spectroscopy (EDS), and UV-Vis scanning spectroscopy, as well as in terms of specific surface area and pore size distribution. Likewise, the effects of important parameters on $\mathrm{AB} 80$ adsorption by the $\mathrm{Cu}-\mathrm{TiO}_{2}$ composite, such as solution $\mathrm{pH}$, initial AB80 concentration, contact time, and temperature, were investigated. Besides this, the adsorption mechanism of $\mathrm{AB} 80$ onto $\mathrm{Cu}-\mathrm{TiO}_{2}$ was assessed in terms of kinetics, equilibrium, and thermodynamics.

\section{Materials and Methods}

2.1. Reagents. Acid blue 80 dye (benzenesulfonic acid, $3,3^{\prime}$ - [(9,10-dihydro-9,10-dioxo-1,4-anthracenediyl) diimino]bis[2,4,6-trimethyl-, disodium salt]) was obtained from Sigma-Aldrich, USA. Stock acid blue 80 (AB80) dye solution was prepared by dissolving $1 \mathrm{~g}$ of the dye in $1 \mathrm{~L}$ of distilled deionized water. Test AB80 solutions were prepared by diluting the stock dye solution. The titanium dioxide $\left(\mathrm{TiO}_{2}\right)$ USP used in this work is commercialized as a food and pharmaceutical additive and was obtained from Químicos De La 13 Ltd., Bogota, Colombia. Analytical grade $\mathrm{CuSO}_{4} \cdot 5 \mathrm{H}_{2} \mathrm{O}$ was obtained from J. T. Baker.

\subsection{Preparation and Characterization of the $\mathrm{Cu}-\mathrm{TiO}_{2} \mathrm{Com}$ -} posite. The $\mathrm{Cu}-\mathrm{TiO}_{2}$ composite samples were prepared as follows: A $10 \mathrm{~g} \mathrm{~L}^{-1} \mathrm{TiO}_{2}$ suspension in water and a $1.25 \mathrm{~g} \mathrm{~L}^{-1}$ $\mathrm{CuSO}_{4} \cdot 5 \mathrm{H}_{2} \mathrm{O}$ solution in ethanol were separately sonicated for $1 \mathrm{~h}$ each; subsequently, the samples were mixed and sonicated for $15 \mathrm{~min}$. The $\mathrm{pH}$ of the resulting suspension was adjusted to 9.0 with $1 \mathrm{M} \mathrm{NaOH}$. Afterwards, the solid was separated by centrifugation, washed with distilled deionized water, oven-dried at $40^{\circ} \mathrm{C}$ for $12 \mathrm{~h}$, and calcined in air at $450^{\circ} \mathrm{C}$ for $1 \mathrm{~h}$.

The resulting $\mathrm{Cu}-\mathrm{TiO}_{2}$ composite was then characterized in terms of specific surface area, pore volume, and average pore diameter using nitrogen adsorption-desorption at $77.35 \mathrm{~K}$, which was conducted using a gas sorption analyzer (Quantachrome, NOVA 4200e series, USA). The specific surface area was determined from isotherms using the BrunauerEmmett-Teller (BET) equation, and the pore size distribution was determined using the Barrett-Joyner-Halenda (BJH) method.

The morphological and surface characteristics of $\mathrm{Cu}$ $\mathrm{TiO}_{2}$ composite were observed using a field emission scanning electron microscope (FE-SEM, JEOL, JSM-7401F) operating at $20 \mathrm{kV}$, equipped with an energy dispersive X-ray spectrometry (EDS) system. The chemical analysis of $\mathrm{Cu}-$ $\mathrm{TiO}_{2}$ composite was determined by EDS.

Analysis of the crystalline phase of $\mathrm{Cu}-\mathrm{TiO}_{2}$ composite was performed by X-ray diffraction (XRD) using PANalytical X'Pert PRO MOD diffractometer, operated with $\mathrm{Cu} \mathrm{K} \alpha$ radiation (wavelength $=1.54050 \AA$ ) at $45 \mathrm{kV}$ and $40 \mathrm{~mA}$. XRD patterns were collected in $2 \theta$ range from 10 to $90^{\circ}$ with a scan rate of $0.026^{\circ}$ per $40 \mathrm{~s}$ and a step size of $0.026^{\circ}$.

The optical properties of the $\mathrm{Cu}-\mathrm{TiO}_{2}$ composite were studied using UV-Vis spectroscopy in the wavelength range of $240-800 \mathrm{~nm}$. The optical band gap $\left(E_{g}\right)$ was estimated following the procedures described by Mathews et al. [22] and Pihosh et al. [23].

2.3. Determination of the Point of Zero Charge (PZC). The $\mathrm{pH}$ at which the adsorbent surface has a neutral net charge is referred to as the point of zero charge (PZC). In the present work, PZC was determined by a batch equilibrium method, following the procedures outlined by Hasan et al. [24].

2.4. Kinetics Studies of AB80 Adsorption and Analytical Methods. Batch kinetics adsorption experiments were conducted 
to assess the influence of solution $\mathrm{pH}$, initial AB80 concentration, shaking contact time, and temperature on AB80 adsorption from aqueous solutions by the $\mathrm{Cu}-\mathrm{TiO}_{2}$ composite. All of the experiments were performed in $500 \mathrm{~mL}$ Erlenmeyer flasks containing $120 \mathrm{~mL}$ of $\mathrm{AB} 80$ solution of known concentration and $1 \mathrm{~g}$ (dry weight) $\mathrm{L}^{-1}$ of $\mathrm{Cu}-\mathrm{TiO}_{2}$. Throughout the course of the experiments, the $\mathrm{pH}$ of each $\mathrm{AB} 80$ solution was maintained at a constant value ( \pm 0.1 units) by periodic checking and adjustment where necessary with $0.1 \mathrm{M} \mathrm{HCl}$ or $\mathrm{NaOH}$ solutions. Flasks were agitated in a shaker at a constant $120 \mathrm{rpm}$ shaking speed. All AB80 adsorption experiments were performed in the dark to avoid dye removal by photocatalytic processes.

The effect of solution $\mathrm{pH}$ levels on $\mathrm{Cu}-\mathrm{TiO}_{2} \mathrm{AB} 80$ adsorption was assessed in AB80 solution at $30 \mathrm{mg} \mathrm{L}^{-1}$ initial dye concentration with different $\mathrm{pH}$ values ranging from 1.0 to $8.0 \pm 0.1$, at $25 \pm 1^{\circ} \mathrm{C}$. To examine the influence of initial AB80 concentration on kinetics performance, experiments were conducted with $\mathrm{AB} 80$ concentrations ranging from 10 to $150 \mathrm{mg} \mathrm{L}^{-1}$, at $25 \pm 1^{\circ} \mathrm{C}$. The effect of temperature on the kinetics of AB80 adsorption was studied by varying temperature from 25 to $60 \pm 1^{\circ} \mathrm{C}$, and two initial AB80 concentrations were used ( 30 and $120 \mathrm{mg} \mathrm{L}^{-1}$ ).

To check for AB80 adsorption onto glass, AB80 precipitation, and/or AB80 photolysis, $\mathrm{Cu}-\mathrm{TiO}_{2}$-free controls were run concurrently and under exactly the same operating conditions as those used for the AB80 adsorption experiments. Throughout the experiments conducted in this work, no change in AB80 concentration was detected in the $\mathrm{Cu}$ $\mathrm{TiO}_{2}$-free controls, which indicates that the observed $\mathrm{AB} 80$ removal in the experiments with the $\mathrm{Cu}-\mathrm{TiO}_{2}$ composite was only due to the adsorbent.

Samples were collected after different times of contact between the $\mathrm{Cu}-\mathrm{TiO}_{2}$ composite and $\mathrm{AB} 80$ solutions and centrifuged at $8000 \mathrm{rpm}$ for $20 \mathrm{~min}$. The supernatants were subsequently analyzed spectrophotometrically (Genesys $10 \mathrm{UV}$ Visible, Thermo Electron Scientific Instruments Corporation) at $626 \mathrm{~nm}$ wavelength to quantify the residual AB80 concentration.

2.5. Equilibrium Studies of AB80 Adsorption. For the equilibrium adsorption experiments, $1 \mathrm{~g} \mathrm{~L}^{-1}$ of $\mathrm{Cu}-\mathrm{TiO}_{2}$ composite was brought into contact with solutions of different initial AB80 concentrations (10-150 $\mathrm{mg} \mathrm{L}^{-1}$ ) at $25^{\circ} \mathrm{C}$, with constant agitation at $120 \mathrm{rpm}$ for $2 \mathrm{~h}$ to ensure adsorption equilibrium was reached. Afterward, samples were collected and centrifuged at $8000 \mathrm{rpm}$ for $20 \mathrm{~min}$, and the obtained supernatants were subsequently analyzed for AB80 concentration.

2.6. Estimation of AB80 Adsorption Capacity. The capacity of AB80 adsorption $\left(q_{t}, \mathrm{mg} \mathrm{g}^{-1}\right)$, which represents the amount of AB80 removed at time $t$ by the unit mass (dry weight) of $\mathrm{Cu}-\mathrm{TiO}_{2}$ composite, was calculated according to the following mass balance relationship:

$$
q_{t}=\frac{\left(C_{0}-C_{t}\right) V}{W}
$$

where $C_{0}$ and $C_{t}\left(\mathrm{mg} \mathrm{L}^{-1}\right)$ are the initial and residual AB80 concentrations at times $t_{0}=0 \mathrm{~h}$ and $t=t(\mathrm{~h})$, respectively, $V$ is the solution volume (L), and $W$ is the dry weight of $\mathrm{Cu}-$ $\mathrm{TiO}_{2}$ composite (g).

2.7. Adsorption Kinetics Modeling. The dynamics of AB80 adsorption onto the $\mathrm{Cu}-\mathrm{TiO}_{2}$ composite were analyzed using the Elovich, fractional power, pseudo-first-order, and pseudo-second-order kinetics models (Table 1), which have been widely used to analyze and understand the adsorption kinetics of dyes by different adsorbents.

2.8. Adsorption Isotherm Modeling. To quantify the relationship between the amount of AB80 adsorbed at equilibrium onto the $\mathrm{Cu}-\mathrm{TiO}_{2}$ composite and the equilibrium solution concentration of AB80, two-parameter (Langmuir, Freundlich, Dubinin-Radushkevich, and Halsey), threeparameter (Sips, Redlich-Peterson, Koble-Corrigan, Toth, and Khan), and four-parameter (Fritz-Schluender) isotherm models (Table 1) were investigated based on the batch equilibrium experimental results.

2.9. Thermodynamic Study. Thermodynamic parameters such as Arrhenius activation energy $\left(E_{A}\right)$ and the changes in activation enthalpy $\left(\Delta H^{*}\right)$, entropy $\left(\Delta S^{*}\right)$, and Gibbs free energy $\left(\Delta G^{*}\right)$ were calculated to describe the thermodynamic behavior of $\mathrm{AB} 80$ adsorption onto $\mathrm{Cu}-\mathrm{TiO}_{2}$ (Table 1).

2.10. Statistical and Data Analysis. Three independent replicates confirmed that the AB80 adsorption experiments were reproducible within a 5\% error, and mean values are reported herein. AB80 adsorption data were statistically analyzed by analysis of variance (ANOVA; Tukey's method; overall confidence level $=0.05$ ) using GraphPad Prism software version $6.0 \mathrm{c}$ (GraphPad Software, Inc.).

All kinetics, isotherm, and thermodynamic parameters of the models were evaluated by nonlinear regression analysis of the experimental data using the MATLAB R2010b software (The MathWorks Inc.). The determination coefficients $\left(r^{2}\right)$, the residual or sum of squares error (SSE), and the root mean squared error or standard error (RMSE) of the estimate, as well as the $95 \%$ confidence intervals of the model parameters, were used with the purpose of measuring the goodness-of-fit of the mathematical models. Good curve fitting was indicated by $r^{2}$ values close to 1.0, small RMSE and SSE values, and narrow $95 \%$ confidence intervals.

\section{Results and Discussion}

3.1. Characterization of the $\mathrm{Cu}-\mathrm{TiO}_{2}$ Composite. The specific surface area and porosity are important characteristics of adsorbents. Surface area and pore size distribution were analyzed by $\mathrm{N}_{2}$ adsorption and desorption studies. The adsorption-desorption isotherm and the derived pore size distributions are illustrated in Figure 1. The $\mathrm{N}_{2}$ isotherm of $\mathrm{Cu}-\mathrm{TiO}_{2}$ is a type IV IUPAC isotherm, which is observed in mesoporous solids. This isotherm also exhibited a type $\mathrm{H} 3$ hysteresis loop (Figure 1(a)), which is characteristic of slitshaped pores [31]. The specific surface area was found to be 


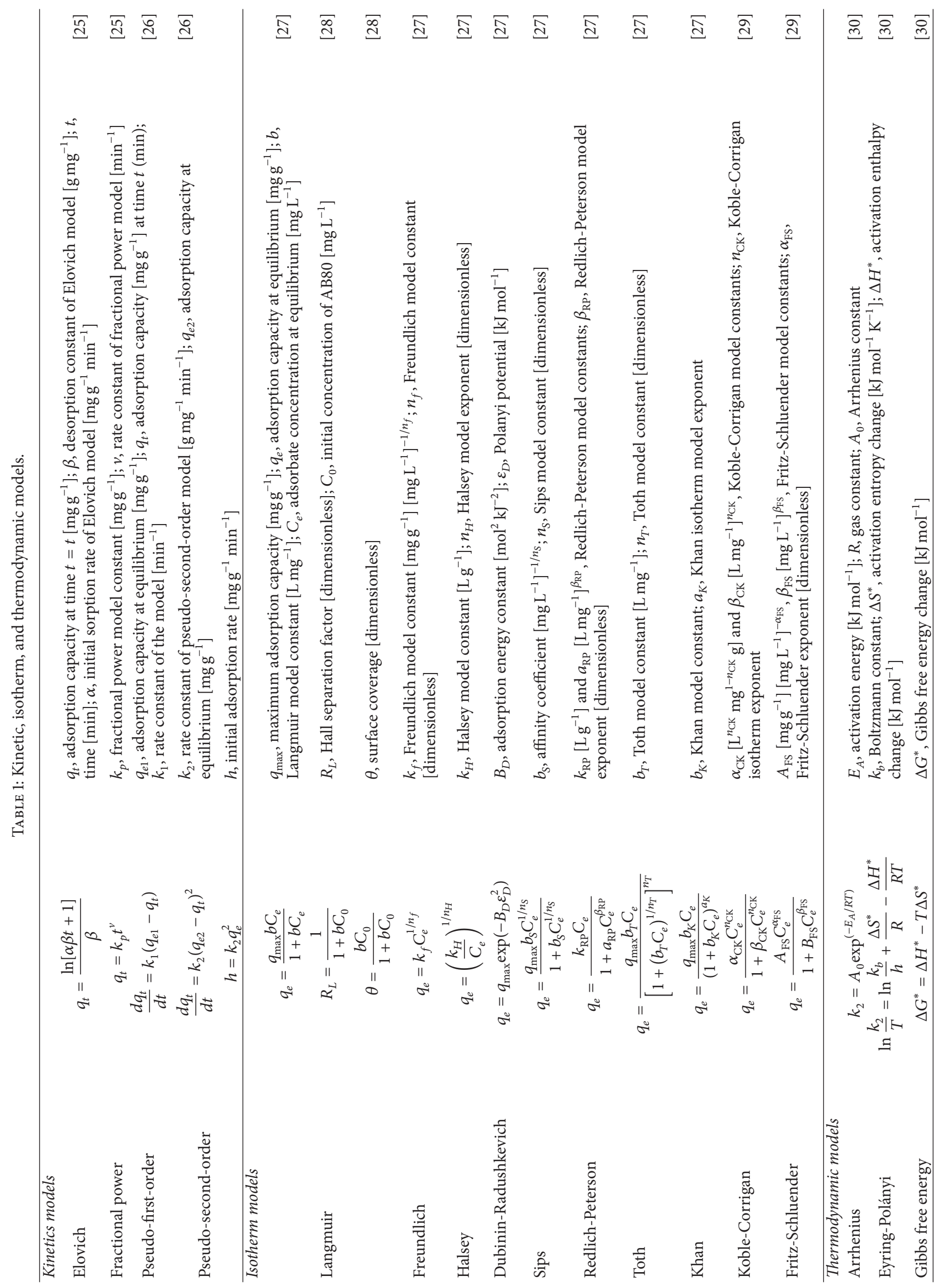




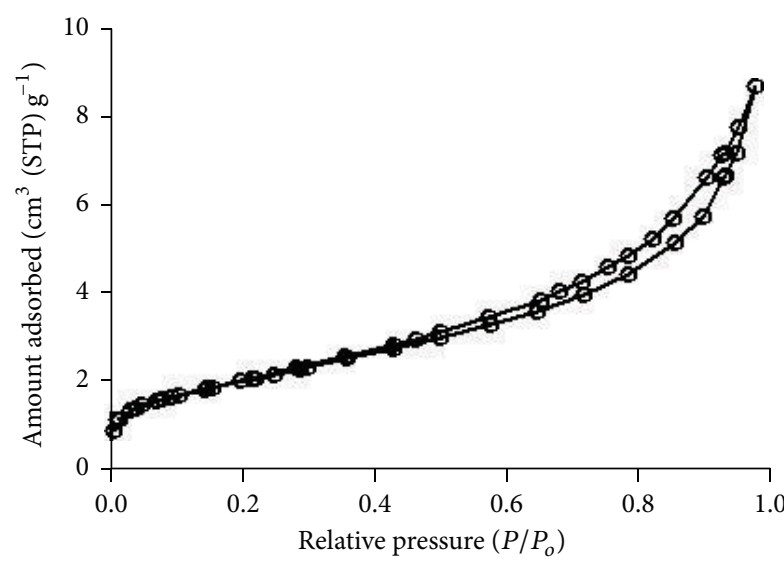

(a)

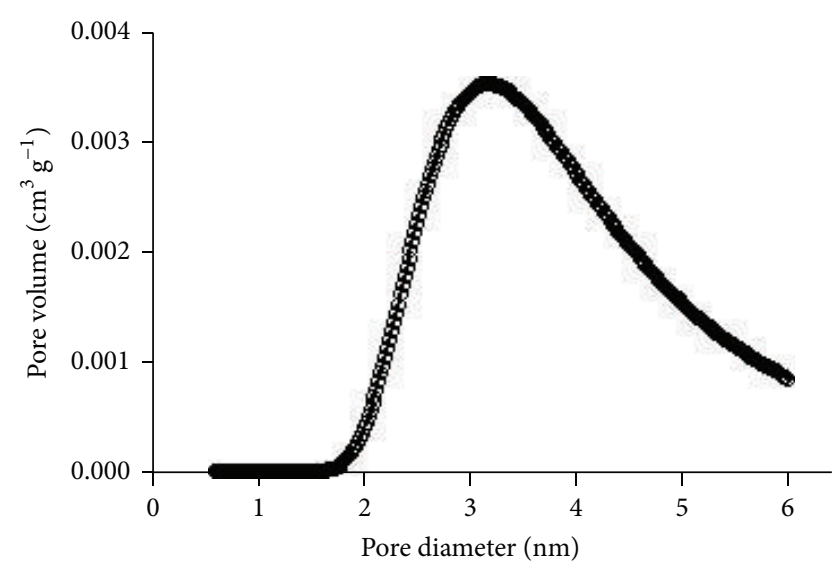

(b)

FIGURE 1: Nitrogen adsorption-desorption isotherm (a) and the corresponding pore size distribution curve (b) for the $\mathrm{Cu}^{-\mathrm{TiO}} \mathrm{F}_{2}$ sample.

TABle 2: Chemical analysis of $\mathrm{Cu}-\mathrm{TiO}_{2}$ composite.

\begin{tabular}{lc}
\hline Element & Weight (\%) \\
\hline $\mathrm{O}$ & 40.21 \\
$\mathrm{Ti}$ & 52.38 \\
$\mathrm{Cu}$ & 6.6 \\
$\mathrm{~S}$ & 0.82 \\
\hline
\end{tabular}

$7.35 \mathrm{~m}^{2} \mathrm{~g}^{-1}$. As it is evident from Figure $1(\mathrm{~b})$, the $\mathrm{Cu}-\mathrm{TiO}_{2}$ sample has an extended mesopore structure with a total pore volume of $0.011 \mathrm{~cm}^{3}$ (STP) $\mathrm{g}^{-1}$ and an average pore diameter of $3.16 \mathrm{~nm}$.

Field emission scanning electron microscopy (FE-SEM) has been widely used to examine the morphological and surface characteristics of different materials. In the present study, FE-SEM micrographs reveal that $\mathrm{Cu}-\mathrm{TiO}_{2}$ particles have a smooth surface, show round to ovoid shape, and form agglomerates of different morphology (Figures 2(a)-2(c)). This is because small copper oxide particles formed during the annealing process accumulate and grow on the $\mathrm{TiO}_{2}$ surface, resulting in the formation of agglomerates of different sizes (140-220 nm). Similar results were previously reported by Villanueva-Jaramillo et al. [32] and Hernández et al. [33], who used similar reaction conditions for the preparation of a $\mathrm{Cu}-\mathrm{TiO}_{2}$ composite.

Results from EDS show that the $\mathrm{Cu}$ content of $\mathrm{Cu}-\mathrm{TiO}_{2}$ composite was high $(6.6 \% \mathrm{w} / \mathrm{w})$ (Figure $2(\mathrm{~d})$, Table 2$)$. Low sulfur content $(0.82 \% \mathrm{w} / \mathrm{w})$ was detected in the composite, whose presence may be due to the incomplete decomposition of the doping precursor $\left(\mathrm{CuSO}_{4}\right)$ at $450^{\circ} \mathrm{C}$.

The XRD patterns of $\mathrm{Cu}-\mathrm{TiO}_{2}$ are shown in Figure 2(e). The diffraction peaks of both anatase phase and rutile phase of $\mathrm{TiO}_{2}$ were well defined. In addition, peaks at $2 \theta$ of $32.4^{\circ}$ and $56.5^{\circ}$ were ascribed to diffraction of (110) and (021) planes of $\mathrm{CuO}$, respectively; while the diffraction peak observed at $2 \theta$ of $42.3^{\circ}$ corresponds to the (200) plane of $\mathrm{Cu}_{2} \mathrm{O}$. The presence of copper oxides in the $\mathrm{Cu}-\mathrm{TiO}_{2}$ composite is due to the doping precursor $\left(\mathrm{CuSO}_{4}\right)$ and to the composite synthesis methodology used in the present work. Under the conditions of the present synthesis method, $\mathrm{Cu}$ from $\mathrm{CuSO}_{4}$ precipitates as $\mathrm{Cu}(\mathrm{OH})_{2}$ on $\mathrm{TiO}_{2}$ under alkaline conditions ( $\mathrm{pH}$ 9.0), which subsequently transforms into copper oxides on annealing at $450^{\circ} \mathrm{C}$.

Figure 2(f) shows that the optical band gap $\left(E_{g}\right)$ shifts from $3.18 \mathrm{eV}(390 \mathrm{~nm})$ for the undoped $\mathrm{TiO}_{2}$ to $2.3 \mathrm{eV}$ $(539 \mathrm{~nm})$ for the $\mathrm{Cu}$-doped $\mathrm{TiO}_{2}$. The observed value of band gap for the $\mathrm{Cu}-\mathrm{TiO}_{2}$ composite is similar to that reported $(2.83 \mathrm{eV})$ by Karunakaran et al. [34] for a $\mathrm{Cu}-\mathrm{TiO}_{2}$ composite capable of degrading organic compounds under visible light irradiation.

In the present work, the photocatalytic performance of $\mathrm{Cu}$-doped $\mathrm{TiO}_{2}$ and undoped $\mathrm{TiO}_{2}$ composites was tested by degrading $10 \mathrm{mg} \mathrm{AB} 80 \mathrm{~L}^{-1}$ under visible light irradiation. The $\mathrm{Cu}$-doped $\mathrm{TiO}_{2}$ exhibited a degradation efficiency of $70 \%$, whereas the undoped $\mathrm{TiO}_{2}$ was not capable of degrading the AB80 dye over a $4 \mathrm{~h}$ period (data not shown). The better photocatalytic performance of $\mathrm{Cu}-\mathrm{TiO}_{2}$ can be attributed to the following reasons. As the valence of $\mathrm{Cu}^{2+}$ ions is less than that of $\mathrm{Ti}^{4+}$, doping with $\mathrm{Cu}$ induces oxygen vacancies, which act as the active sites for water dissociation on the surface of $\mathrm{TiO}_{2}$ and can also act as charge carriers of holes (positive effect), while facilitating the separation of photoinduced electronhole pairs. Oxygen vacancies can efficiently transfer photoinduced electrons to reduce the recombination of electron-hole pairs and thus enhance the visible light photocatalytic activity of $\mathrm{TiO}_{2}[15,35,36]$. Furthermore, the $\mathrm{Cu}-\mathrm{TiO}_{2}$ composite exhibits an enhanced light harvest in both the UV and visible light regions, enabling much more light energy to be utilized for photocatalysis [36].

3.2. Determination of Point of Zero Charge (PZC). The surface charge of $\mathrm{Cu}-\mathrm{TiO}_{2}$ highly depends on the solution $\mathrm{pH}$ and affects its adsorption capacity and consequently the photocatalytic oxidation. The $\mathrm{pH}$ at which the net charge of the adsorbent is zero is known as the point of zero charge (PZC) or isoelectric point, and it can be used to assess the adsorbent surface charge qualitatively [19]. 


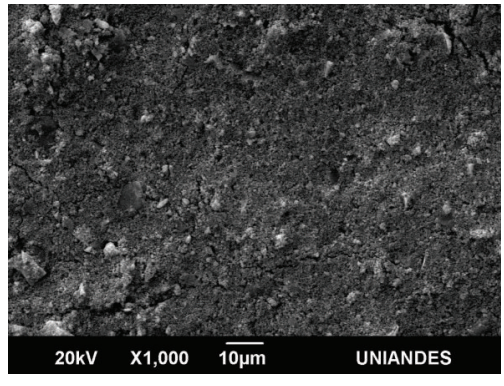

(a)

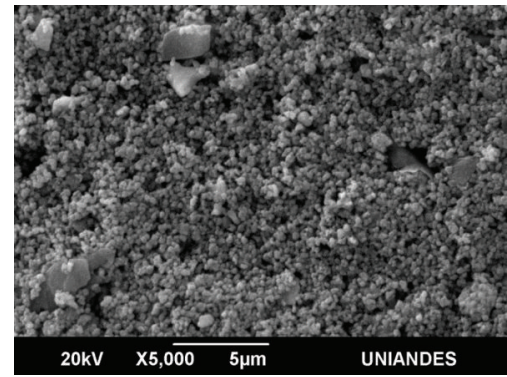

(b)

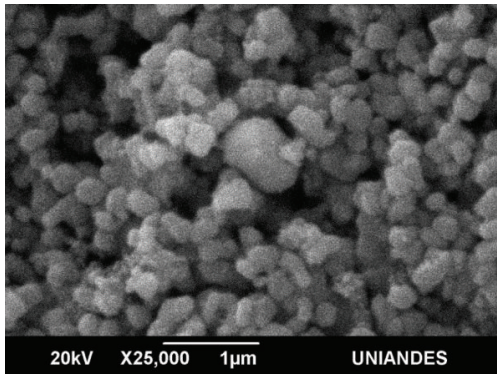

(c)

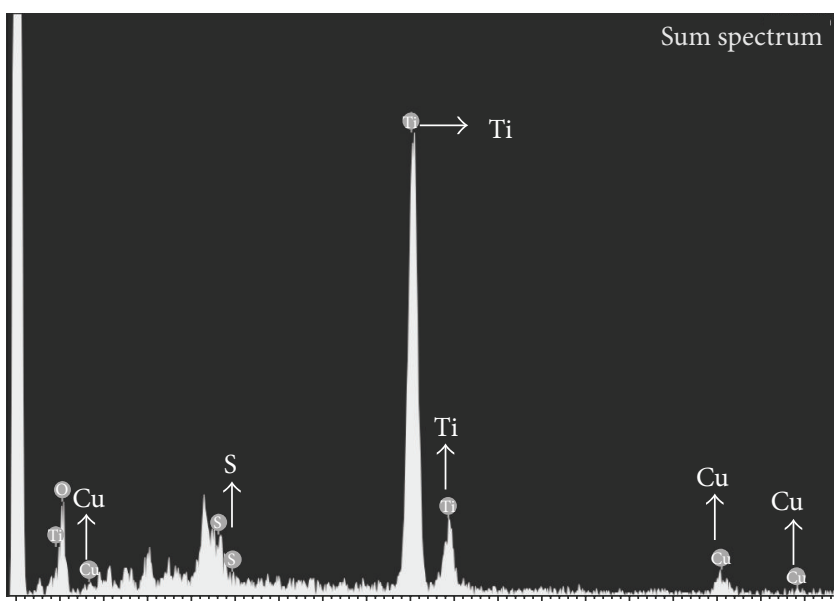

$\begin{array}{lllllllllllllllllll}0 & 0.5 & 1 & 1.5 & 2 & 2.5 & 3 & 3.5 & 4 & 4.5 & 5 & 5.5 & 6 & 6.5 & 7 & 7.5 & 8 & 8.5 & 9\end{array}$

$(\mathrm{keV})$

Full-scale 280 cts cursor: -0.102 ( 0 cts)

(d)

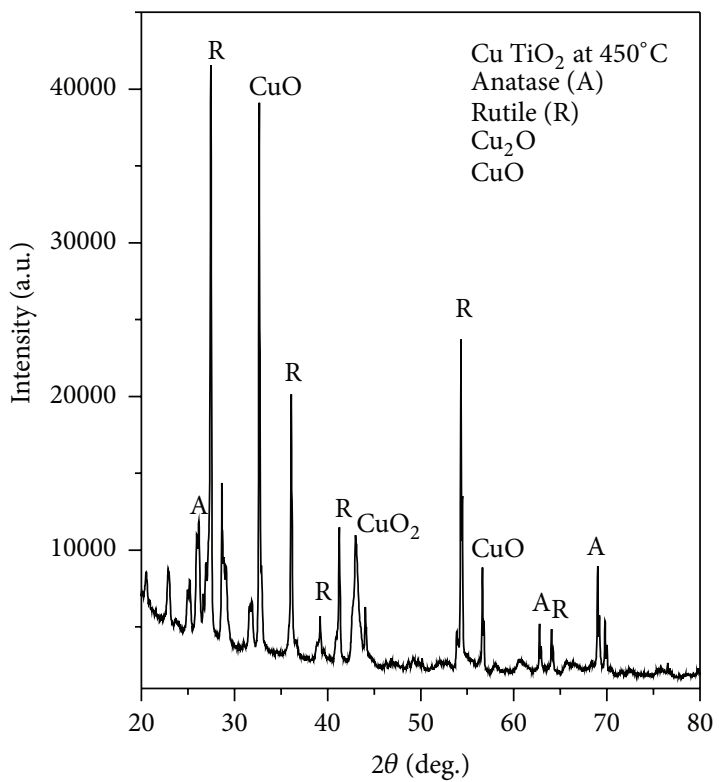

(e)

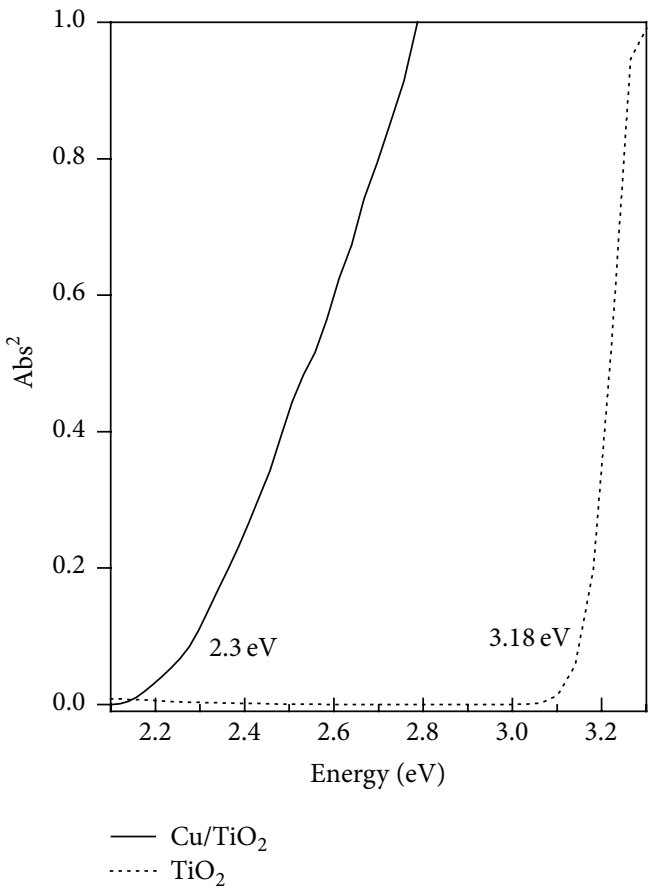

(f)

FIgURE 2: Characterization of $\mathrm{Cu}-\mathrm{TiO}_{2}$ composite by FE-SEM (a-c), EDS (d), XRD (e), and UV-Vis scanning (f). 

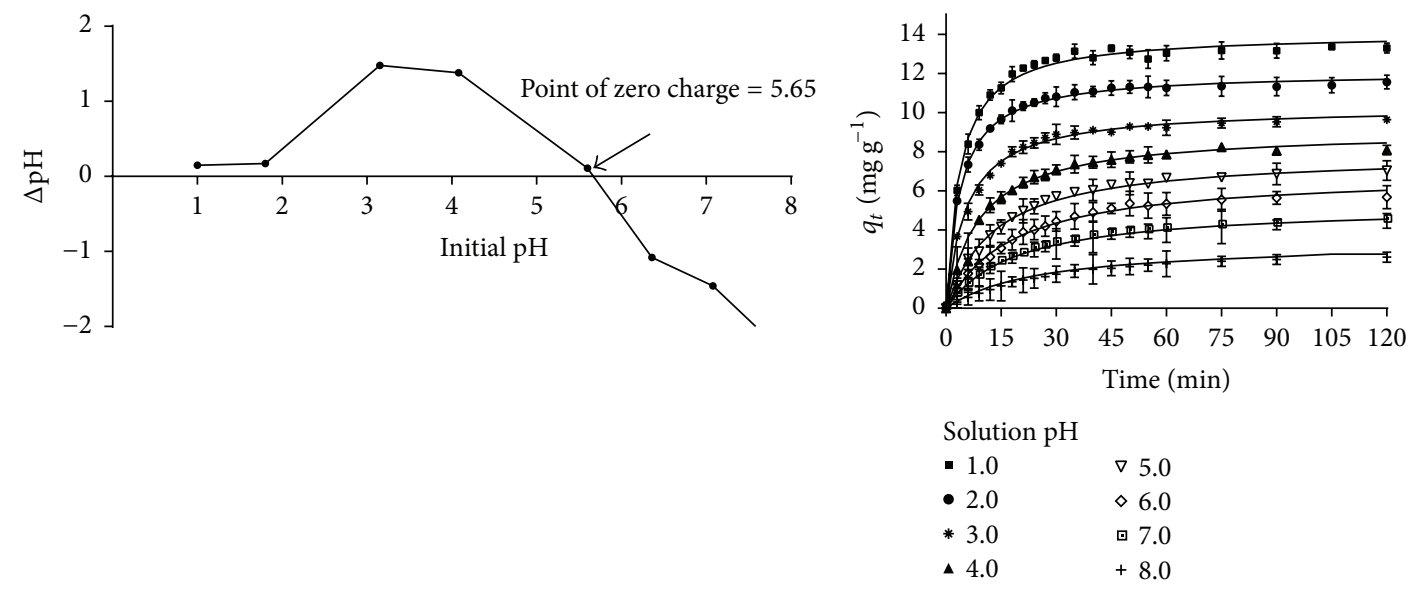

(a)

(b)

FIgure 3: (a) Determination of point of zero charge of $\mathrm{Cu}_{-} \mathrm{TiO}_{2}$. (b) Effect of solution $\mathrm{pH}$ on the $\mathrm{AB} 80$ adsorption capacity of $\mathrm{Cu}-\mathrm{TiO}{ }_{2}$.

The PZC of $\mathrm{Cu}-\mathrm{TiO}_{2}$ was found to be 5.65 (Figure 3(a)). Hence, for solution $\mathrm{pH}$ values lower than 5.65 , the surface of the $\mathrm{Cu}-\mathrm{TiO}_{2}$ becomes positively charged, and the opposite occurs for solutions with $\mathrm{pH}$ higher than 5.65.

The $\mathrm{PZC}$ of $\mathrm{Cu}-\mathrm{TiO}_{2}$ is different from that reported for $\mathrm{TiO}_{2}$, which ranges from 6.2 to 6.9 [19], and this can be ascribed to the addition of the doping metal [Cu(II)]. This result is in agreement with other studies that have shown that PZC depends on the chemical composition of both the particle surfaces and the surrounding solvent $[19,37,38]$.

3.3. Effect of $p H$ on $A B 80$ Adsorption Kinetics. The $\mathrm{pH}$ of a dye solution is a key environmental parameter in the adsorption process because it affects the surface charge of the adsorbent, the ionization state of the dye molecule, and the solubility of dyes in the aqueous solution $[39,40]$.

Figure 3(b) shows the variations in $\mathrm{AB} 80$ adsorption capacity of $\mathrm{Cu}-\mathrm{TiO}_{2}$ with respect to contact time at different $\mathrm{pH}$ values ranging from 1.0 to 8.0. It is evident that the adsorption of $\mathrm{AB} 80$ onto the $\mathrm{Cu}-\mathrm{TiO}_{2}$ composite showed strong $\mathrm{pH}$ dependence. The capacity of $\mathrm{Cu}-\mathrm{TiO}_{2}$ for adsorbing $\mathrm{AB} 80$ increased as the solution $\mathrm{pH}$ decreased and reached its highest level at $\mathrm{pH}$ 1.0. A similar behavior has been observed in the adsorption of reactive red 198 on $\mathrm{TiO}_{2}$ [41], acid green 25 on alginate- $\mathrm{TiO}_{2}$ [42], and $\mathrm{N} 719$ on $\mathrm{TiO}_{2}$ [43].

The interpretation of the effect of solution $\mathrm{pH}$ on $\mathrm{AB} 80$ adsorption onto $\mathrm{Cu}-\mathrm{TiO}_{2}$ can be well-explained with the help of the $\mathrm{PZC}$ of $\mathrm{Cu}-\mathrm{TiO}_{2}$. For $\mathrm{AB} 80$ solutions with $\mathrm{pH}<\mathrm{PZC}$ (i.e., below pH 5.65), the net surface charge of $\mathrm{Cu}-\mathrm{TiO}_{2}$ is positive due to the adsorption of protons $\left(\mathrm{H}^{+}\right.$and $\left.\mathrm{H}_{3} \mathrm{O}^{+}\right)$, which favored the adsorption of anionic $\mathrm{AB} 80$ due to electrostatic attraction. In contrast, the decrease in AB80 adsorption capacity observed at $\mathrm{pH}$ values of dye solution > PZC may be due to the electrostatic repulsion between the negatively charged $\mathrm{Cu}-\mathrm{TiO}_{2}$ surface and the anionic $\mathrm{AB} 80$ dye and also to the competition between $\mathrm{OH}^{-}$ions and $\mathrm{AB} 80$ molecules for occupancy of the binding sites $[4,42,44]$. However, the $\mathrm{Cu}-\mathrm{TiO}_{2}$ composite could still adsorb AB80 dye at higher solution $\mathrm{pH}$, which indicates that the electrostatic mechanism was not the only mechanism for $\mathrm{AB} 80$ adsorption in this system. $\mathrm{Cu}-\mathrm{TiO}_{2}$ could also adsorb $\mathrm{AB} 80$ dye molecules via hydrogen bonding and hydrophobic mechanisms [45]. Nevertheless, the $\mathrm{AB} 80$ adsorption capacity of $\mathrm{Cu}-\mathrm{TiO}_{2}$ at solution $\mathrm{pH}$ values $<\mathrm{PZC}$ was much higher than that obtained at $\mathrm{pH}>\mathrm{PZC}$, suggesting that the electrostatic interaction was the main mechanism.

The optimal solution $\mathrm{pH}$ for $\mathrm{AB} 80$ adsorption onto the $\mathrm{Cu}-\mathrm{TiO}_{2}$ composite was 1.0, and this $\mathrm{pH}$ was therefore used in further experiments.

\subsection{Influence of Contact Time and Initial AB80 Concentration} on Dye Adsorption. Figure 4 shows the variations in AB80 adsorption capacity with respect to adsorption time at different initial $\mathrm{AB} 80$ concentrations ranging from 10 to $150 \mathrm{mg} \mathrm{L}^{-1}$. At all of the tested initial dye concentrations, AB80 adsorption capacity gradually rose as experimental adsorption time passed until adsorption capacity reached a maximum constant value that corresponded to the equilibrium adsorption capacity $\left(\exp q_{e}\right)$ value. Likewise, regardless of initial $\mathrm{AB} 80$ concentration, the rate of the $\mathrm{AB} 80$ adsorption process was fast during the first $15 \mathrm{~min}$ of contact time, and this may be because a large number of positively charged active sites are available for adsorption of $\mathrm{AB} 80$ on the $\mathrm{Cu}$ $\mathrm{TiO}_{2}$ surface. Thereafter, AB80 adsorption rate decreased gradually until the dynamic equilibrium was reached within the first $60 \mathrm{~min}$; at this point, the active $\mathrm{Cu}-\mathrm{TiO}_{2}$ sites were all occupied by $\mathrm{AB} 80$ molecules. The short duration of the present experiments indicates that the $\mathrm{AB} 80$ adsorption is kinetics-controlled rather than diffusion-controlled process [19]. It is clear from Figure 4 that the AB80 adsorption capacity increased as the initial dye concentration increased from 10 to $90 \mathrm{mg} \mathrm{L}^{-1}$. This effect may be due to the higher availability of AB80 molecules in aqueous solution, which enhanced the interaction between the $\mathrm{AB} 80$ dye molecules and the $\mathrm{Cu}$ $\mathrm{TiO}_{2}$ composite. Higher AB80 concentration also increases the driving force of the dye concentration gradient to overcome the resistance to the mass transfer of $\mathrm{AB} 80$ between the aqueous phase and the solid phase of $\mathrm{Cu}-\mathrm{TiO}_{2}$, which 
TABLE 3: Effect of the initial AB80 concentration on the kinetics parameters of the models for $\mathrm{AB} 80$ adsorption onto $\mathrm{Cu}-\mathrm{TiO} \mathrm{O}_{2}$.

(a)

\begin{tabular}{lccccccccccccc}
\hline $\begin{array}{l}C_{0} \\
{\left[\mathrm{mg} \mathrm{L}^{-1}\right]}\end{array}$ & $\begin{array}{c}\exp q_{e} \\
{\left[\mathrm{mg} \mathrm{g}^{-1}\right]}\end{array}$ & $\begin{array}{c}\exp t_{e} \\
{[\mathrm{~min}]}\end{array}$ & $\begin{array}{c}\alpha \\
{\left[\mathrm{mg} \mathrm{g}^{-1} \mathrm{~min}^{-1}\right]}\end{array}$ & $\begin{array}{c}\beta \\
{\left[\mathrm{g} \mathrm{mg}^{-1}\right]}\end{array}$ & $r^{2}$ & SSE & RMSE & $\begin{array}{c}k_{p} \\
{\left[\mathrm{mg} \mathrm{min}^{-1}\right]}\end{array}$ & $\begin{array}{c}v \\
{\left[\mathrm{~min}^{-1}\right]}\end{array}$ & $r^{2}$ & SSE & RMSE \\
\hline 10 & 3.395 & 21 & $0.803 \pm 0.290$ & $1.310 \pm 0.170$ & 0.978 & 0.320 & 0.146 & $1.010 \pm 0.20$ & $0.277 \pm 0.053$ & 0.95 & 0.752 & 0.224 \\
20 & 7.725 & 21 & $11.50 \pm 6.260$ & $0.850 \pm 0.098$ & 0.983 & 1.063 & 0.250 & $3.610 \pm 0.40$ & $0.175 \pm 0.029$ & 0.96 & 2.087 & 0.350 \\
30 & 11.60 & 21 & $2.842 \pm 1.320$ & $0.380 \pm 0.063$ & 0.957 & 8.664 & 0.675 & $3.590 \pm 0.84$ & $0.269 \pm 0.061$ & 0.91 & 17.86 & 0.969 \\
40 & 12.67 & 24 & $8.587 \pm 5.740$ & $0.435 \pm 0.074$ & 0.953 & 9.929 & 0.722 & $5.330 \pm 0.97$ & $0.204 \pm 0.048$ & 0.92 & 16.76 & 0.939 \\
50 & 14.00 & 27 & $21.43 \pm 20.30$ & $0.473 \pm 0.090$ & 0.946 & 12.46 & 0.809 & $6.740 \pm 1.13$ & $0.168 \pm 0.045$ & 0.91 & 18.77 & 0.994 \\
70 & 17.06 & 30 & $47.79 \pm 46.21$ & $0.468 \pm 0.813$ & 0.963 & 10.26 & 0.735 & $8.280 \pm 1.08$ & $0.149 \pm 0.035$ & 0.94 & 15.55 & 0.905 \\
90 & 18.46 & 30 & $32.61 \pm 36.42$ & $0.356 \pm 0.803$ & 0.932 & 29.03 & 1.236 & $9.340 \pm 1.60$ & $0.163 \pm 0.048$ & 0.90 & 41.34 & 1.475 \\
120 & 18.71 & 40 & $77.24 \pm 117.1$ & $0.422 \pm 0.107$ & 0.927 & 27.62 & 1.206 & $10.10 \pm 1.64$ & $0.139 \pm 0.005$ & 0.90 & 35.94 & 1.375 \\
150 & 19.43 & 40 & $74.65 \pm 92.25$ & $0.412 \pm 0.080$ & 0.949 & 19.56 & 1.015 & $10.14 \pm 1.40$ & $0.142 \pm 0.039$ & 0.93 & 26.95 & 1.191 \\
\hline
\end{tabular}

(b)

\begin{tabular}{lccccccccccc}
\hline $\begin{array}{l}C_{0} \\
{\left[\mathrm{mg} \mathrm{L}^{-1}\right]}\end{array}$ & $\begin{array}{c}k_{1} \\
{\left[\mathrm{~min}^{-1}\right]}\end{array}$ & $\begin{array}{c}q_{e 1} \\
{\left[\mathrm{mg} \mathrm{g}^{-1}\right]}\end{array}$ & $r^{2}$ & SSE & RMSE & $\begin{array}{c}k_{2} \\
{\left[\mathrm{~g} \mathrm{mg}^{-1} \mathrm{~min}^{-1}\right]}\end{array}$ & $\begin{array}{c}q_{e 2} \\
{\left[\mathrm{mg} \mathrm{g}^{-1}\right]}\end{array}$ & $\begin{array}{c}h \\
{\left[\mathrm{mg} \mathrm{g}^{-1} \mathrm{~min}^{-1}\right]}\end{array}$ & $r^{2}$ & SSE & RMSE \\
\hline 10 & $0.071 \pm 0.012$ & $3.278 \pm 0.154$ & 0.971 & 0.425 & 0.168 & $0.028 \pm 0.004$ & $3.782 \pm 0.13$ & 0.400 & 0.991 & 0.135 & 0.09 \\
20 & $0.135 \pm 0.135$ & $7.305 \pm 0.306$ & 0.944 & 3.622 & 0.462 & $0.022 \pm 0.004$ & $8.016 \pm 0.19$ & 1.414 & 0.990 & 0.630 & 0.19 \\
30 & $0.076 \pm 0.005$ & $11.19 \pm 0.210$ & 0.993 & 1.269 & 1.384 & $0.015 \pm 0.002$ & $12.74 \pm 0.25$ & 2.435 & 0.996 & 0.296 & 0.47 \\
40 & $0.105 \pm 0.093$ & $12.39 \pm 0.280$ & 0.984 & 2.424 & 3.411 & $0.014 \pm 0.0004$ & $13.83 \pm 0.31$ & 2.678 & 0.992 & 1.661 & 0.29 \\
50 & $0.134 \pm 0.013$ & $13.32 \pm 0.250$ & 0.987 & 1.403 & 3.080 & $0.012 \pm 0.002$ & $14.91 \pm 0.23$ & 2.668 & 0.995 & 1.153 & 0.24 \\
70 & $0.165 \pm 0.330$ & $14.97 \pm 0.022$ & 0.976 & 6.476 & 0.584 & $0.012 \pm 1.000$ & $17.71 \pm 0.23$ & 3.763 & 0.997 & 1.141 & 0.25 \\
90 & $0.145 \pm 0.012$ & $17.99 \pm 0.270$ & 0.990 & 4.029 & 0.461 & $0.011 \pm 0.002$ & $19.72 \pm 0.41$ & 4.278 & 0.994 & 3.708 & 0.44 \\
120 & $0.177 \pm 0.017$ & $17.47 \pm 0.270$ & 0.989 & 4.235 & 0.472 & $0.011 \pm 0.002$ & $19.80 \pm 0.37$ & 4.312 & 0.994 & 3.499 & 0.43 \\
150 & $0.175 \pm 0.022$ & $17.74 \pm 0.360$ & 0.980 & 7.540 & 0.630 & $0.011 \pm 0.001$ & $19.83 \pm 0.30$ & 4.326 & 0.995 & 2.171 & 0.33 \\
\hline
\end{tabular}

increases the probability of collision between AB80 molecules and active $\mathrm{Cu}-\mathrm{TiO}_{2}$ sites and thus leads to enhanced adsorption capacity [4, 45-48]. In contrast, at initial AB80 concentrations between 90 and $150 \mathrm{mg} \mathrm{L}^{-1}$, the adsorption capacities were very similar; this was probably due to the saturation of the adsorption active sites. It is apparent from the above results that saturation of the $\mathrm{Cu}-\mathrm{TiO}_{2}$ surface with $\mathrm{AB} 80$ molecules is dependent on initial dye concentration.

The contact time required to reach equilibrium is an important parameter from a practical and economical point of view. As seen in Table 3 , the equilibrium time $\left(\exp t_{e}\right)$ increased from 21 to $40 \mathrm{~min}$ with increasing initial AB80 concentration from 10 to $150 \mathrm{mg} \mathrm{L}^{-1}$, and this increase was observed because $\mathrm{Cu}-\mathrm{TiO}_{2}$ adsorbed larger amounts of $\mathrm{AB} 80$ as the initial dye concentration increased.

3.5. Effect of Temperature on AB80 Adsorption. Figure 5 shows that, at the two initial AB80 concentrations (30 and $120 \mathrm{mg} \mathrm{L}^{-1}$ ) tested, the $\mathrm{Cu}-\mathrm{TiO}_{2}$ AB80 adsorption capacity and rate increased with rising temperature of the adsorption system from 25 to $60^{\circ} \mathrm{C}$, and consequently the time required to reach equilibrium decreased as the temperature increased

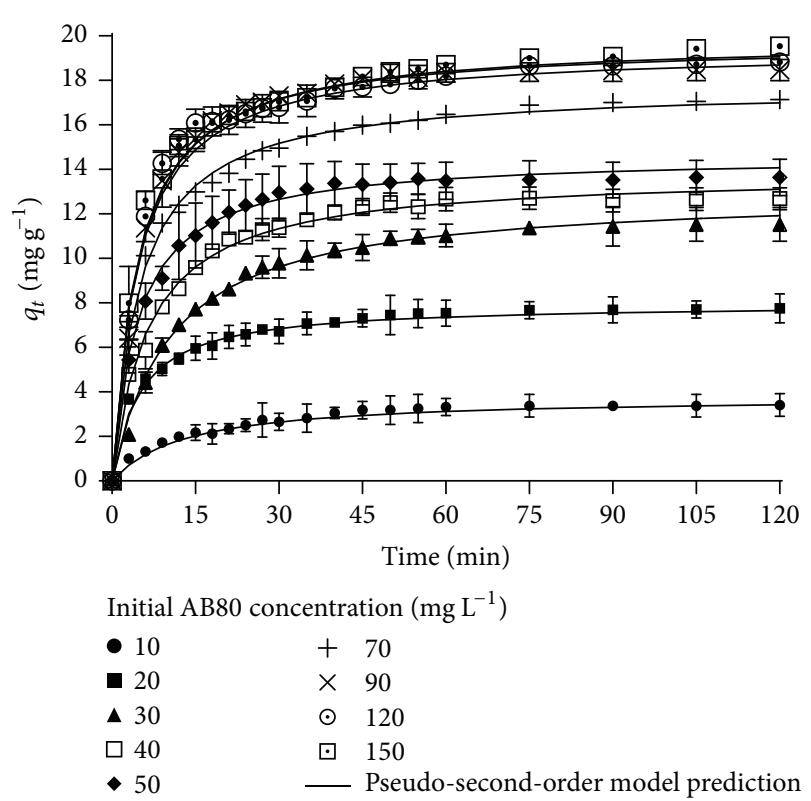

Figure 4: Influence of initial AB80 concentration on the AB80 adsorption capacity of $\mathrm{Cu}-\mathrm{TiO}_{2}$. 
TABLE 4: Kinetics model parameters for $\mathrm{AB} 80$ adsorption onto $\mathrm{Cu}-\mathrm{TiO}_{2}$ at different temperatures.

(a)

\begin{tabular}{|c|c|c|c|c|c|c|c|c|c|c|c|c|c|}
\hline \multirow[b]{2}{*}{$\begin{array}{l}C_{0} \\
{\left[\mathrm{mg} \mathrm{L}^{-1} .\right.}\end{array}$} & \multirow[b]{2}{*}{$\begin{array}{l}\mathrm{T} \\
\left.{ }^{\circ} \mathrm{C}\right]\end{array}$} & \multirow[b]{2}{*}{$\begin{array}{c}\exp q_{e} \\
{\left[\mathrm{mg} \mathrm{g}^{-1}\right]}\end{array}$} & \multirow[b]{2}{*}{$\begin{array}{l}\exp t_{e} \\
{[\min ]}\end{array}$} & \multicolumn{5}{|c|}{ Elovich } & \multicolumn{5}{|c|}{ Fractional power } \\
\hline & & & & {$\left[\mathrm{mg} \mathrm{g}^{-1} \min ^{-1}\right]$} & $\begin{array}{c}\beta \\
{\left[\mathrm{g} \mathrm{mg}^{-1}\right]}\end{array}$ & $r^{2}$ & SSE & RMSE & $\begin{array}{c}k_{p} \\
{\left[\mathrm{mg} \mathrm{min}^{-1}\right]}\end{array}$ & $\begin{array}{c}v \\
{\left[\min ^{-1}\right]}\end{array}$ & $r^{2}$ & SSE & RMSE \\
\hline \multirow{4}{*}{30} & 25 & 11.5 & 35 & $2.816 \pm 1.290$ & $0.381 \pm 0.062$ & 0.959 & 8.435 & 0.666 & $3.581 \pm 0.832$ & $0.270 \pm 0.060$ & 0.914 & 17.59 & 0.962 \\
\hline & 40 & 13.1 & 30 & $7.927 \pm 5.430$ & $0.412 \pm 0.075$ & 0.948 & 12.19 & 0.801 & $5.378 \pm 0.941$ & $0.209 \pm 0.052$ & 0.912 & 20.52 & 1.039 \\
\hline & 50 & 14.8 & 24 & $12.17 \pm 9.820$ & $0.392 \pm 0.076$ & 0.942 & 16.59 & 0.934 & $6.483 \pm 1.254$ & $0.193 \pm 0.051$ & 0.907 & 26.37 & 1.178 \\
\hline & 60 & 15.9 & 21 & $28.49 \pm 27.1$ & $0.418 \pm 0.079$ & 0.950 & 15.15 & 0.893 & $7.948 \pm 1.246$ & $0.165 \pm 0.042$ & 0.926 & 22.43 & 1.086 \\
\hline \multirow{4}{*}{120} & 25 & 18.6 & 45 & $3.392 \pm 1.350$ & $0.219 \pm 0.035$ & 0.964 & 20.28 & 1.033 & $5.089 \pm 1.237$ & $0.297 \pm 0.062$ & 0.918 & 45.08 & 1.540 \\
\hline & 40 & 20.8 & 24 & $8.969 \pm 5.521$ & $0.246 \pm 0.044$ & 0.949 & 30.9 & 1.275 & $7.736 \pm 1.641$ & $0.228 \pm 0.056$ & 0.909 & 54.32 & 1.691 \\
\hline & 50 & 22.7 & 20 & $16.35 \pm 12.53$ & $0.243 \pm 0.047$ & 0.942 & 41.15 & 1.472 & $9.804 \pm 1.946$ & $0.201 \pm 0.052$ & 0.907 & 65.92 & 1.863 \\
\hline & 60 & 25.4 & 18 & $157.1 \pm 218.0$ & $0.317 \pm 0.069$ & 0.949 & 36.08 & 0.947 & $14.59 \pm 1.990$ & $0.132 \pm 0.037$ & 0.932 & 48.37 & 1.596 \\
\hline
\end{tabular}

(b)

\begin{tabular}{lcccccccccccc}
\hline $\begin{array}{c}C_{0} \\
{\left[\mathrm{mg} \mathrm{L}^{-1}\right]}\end{array}$ & $\begin{array}{c}T \\
{\left[{ }^{\circ} \mathrm{C}\right]}\end{array}$ & $\begin{array}{c}k_{1} \\
{\left[\mathrm{~min}^{-1}\right]}\end{array}$ & $\begin{array}{c}q_{e 1} \\
{\left[\mathrm{mg} \mathrm{g}^{-1}\right]}\end{array}$ & $r^{2}$ & SSE & RMSE & $\begin{array}{c}k_{2} \\
{\left[\mathrm{~g} \mathrm{mg}^{-1} \mathrm{~min}^{-1}\right]}\end{array}$ & $\begin{array}{c}q_{e 2} \\
{\left[\mathrm{mg} \mathrm{g}^{-1}\right]}\end{array}$ & $\begin{array}{c}h \\
{\left[\mathrm{mg} \mathrm{g}^{-1} \mathrm{~min}^{-1}\right]}\end{array}$ & $r^{2}$ & SSE & $\mathrm{RMSE}^{2}$ \\
\hline \multirow{3}{*}{30} & 25 & $0.075 \pm 0.005$ & $11.21 \pm 0.22$ & 0.992 & 1.466 & 0.278 & $0.007 \pm 0.001$ & $12.97 \pm 0.32$ & 1.177 & 0.994 & 1.200 & 0.251 \\
& 40 & $0.107 \pm 0.009$ & $12.71 \pm 0.24$ & 0.989 & 2.534 & 0.365 & $0.011 \pm 0.001$ & $14.27 \pm 0.32$ & 2.240 & 0.992 & 1.811 & 0.309 \\
& 50 & $0.118 \pm 0.008$ & $14.25 \pm 0.22$ & 0.992 & 2.183 & 0.339 & $0.012 \pm 0.001$ & $15.86 \pm 0.32$ & 3.018 & 0.995 & 2.014 & 0.326 \\
& 60 & $0.139 \pm 0.016$ & $15.44 \pm 0.35$ & 0.979 & 6.189 & 0.571 & $0.013 \pm 0.001$ & $16.90 \pm 0.34$ & 3.713 & 0.992 & 2.497 & 0.363 \\
\hline \multirow{3}{*}{120} & 25 & $0.068 \pm 0.005$ & $18.02 \pm 0.39$ & 0.992 & 4.381 & 0.480 & $0.004 \pm 0.001$ & $21.19 \pm 0.01$ & 1.796 & 0.996 & 3.773 & 0.446 \\
& 40 & $0.096 \pm 0.007$ & $19.88 \pm 0.37$ & 0.991 & 5.428 & 0.535 & $0.006 \pm 0.001$ & $22.54 \pm 0.59$ & 3.048 & 0.994 & 5.213 & 0.524 \\
& 50 & $0.110 \pm 0.009$ & $22.32 \pm 0.39$ & 0.991 & 7.712 & 0.694 & $0.008 \pm 0.001$ & $24.91 \pm 0.61$ & 4.964 & 0.994 & 6.695 & 0.594 \\
& 60 & $0.187 \pm 0.020$ & $24.54 \pm 0.40$ & 0.987 & 9.586 & 0.710 & $0.012 \pm 0.001$ & $26.47 \pm 0.31$ & 8.408 & 0.996 & 2.689 & 0.376 \\
\hline
\end{tabular}

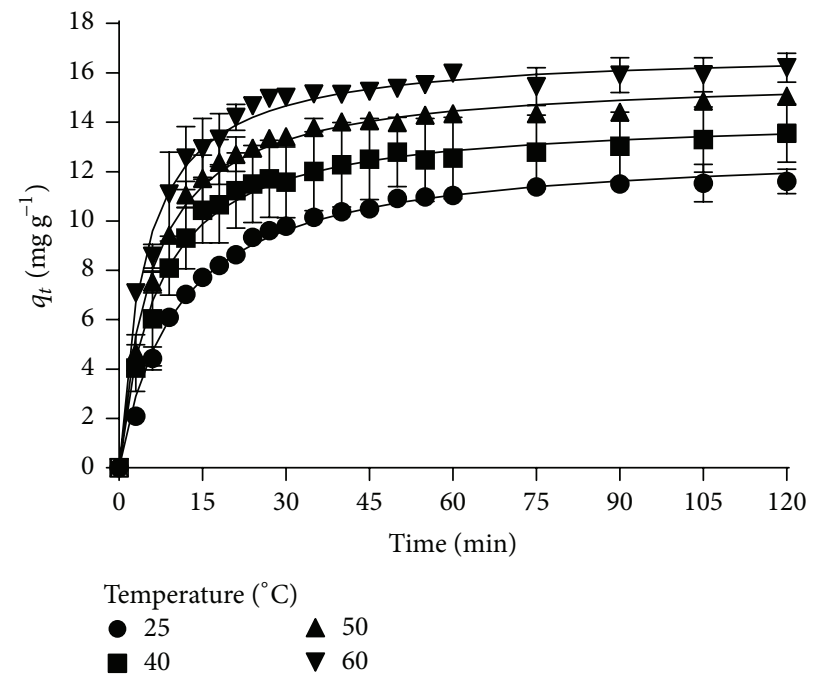

(a)

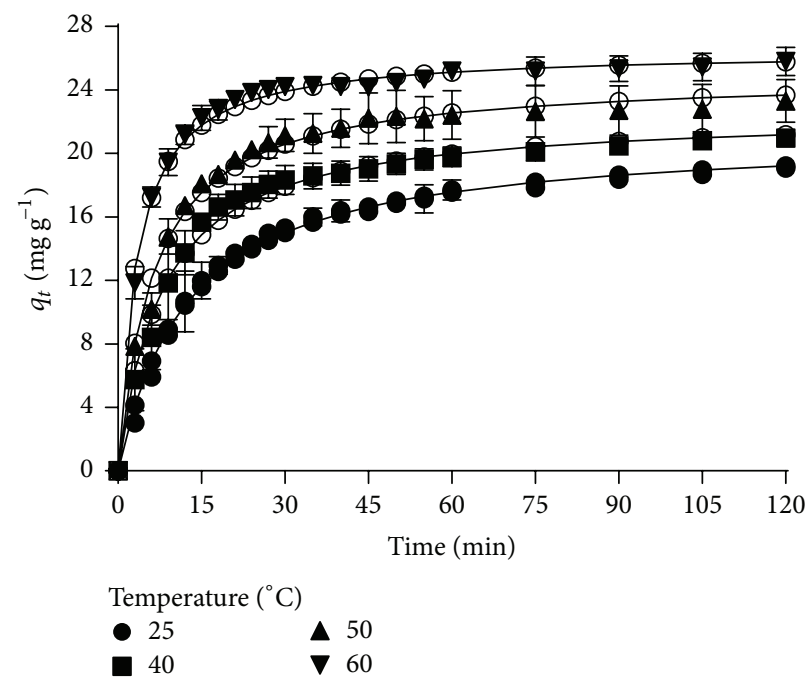

(b)

Figure 5: Kinetics of $\mathrm{AB} 80$ adsorption onto $\mathrm{Cu}-\mathrm{TiO}_{2}$ at different temperatures. Initial $\mathrm{AB} 80$ concentration: (a) $30 \mathrm{mg} \mathrm{L} \mathrm{L}^{-1}$; (b) $120 \mathrm{mg} \mathrm{L} \mathrm{L}^{-1}$.

(Table 4). These results indicate that the adsorption process was endothermic in nature and that a chemical reaction between AB80 molecules and the $\mathrm{Cu}-\mathrm{TiO}_{2}$ surface is involved in the adsorption process [49].
The larger AB80 adsorption capacity and rate at higher temperature may be due to the following: (1) an increase in kinetic energy, which facilitates the diffusion of dye molecules to the active $\mathrm{Cu}-\mathrm{TiO}_{2}$ adsorption sites, (2) a decrease in 
the thickness of the boundary layer surrounding the adsorbent, which, in turn, decreases the mass transfer resistance of dye molecules in the boundary layer, and (3) an increase in the $\mathrm{Cu}-\mathrm{TiO}_{2}$ surface activity $[44,50]$.

3.6. Kinetics Modeling of AB80 Adsorption onto $\mathrm{Cu}-\mathrm{TiO}_{2}$. Kinetics profiles of $\mathrm{AB} 80$ adsorption were modeled to determine the rate-controlling mechanisms involved in the adsorption process. For this purpose, the Elovich, fractional power, pseudo-first-order, and pseudo-second-order kinetics models were used to analyze the experimental adsorption data at different initial AB80 concentrations and temperatures.

Tables 3 and 4 list the experimental equilibrium adsorption capacity $\left(\exp q_{e}\right)$, the parameter values of the Elovich $(\alpha$ and $\beta)$, fractional power $\left(k_{p}\right.$ and $\left.v\right)$, pseudo-first-order $\left(k_{1}\right.$ and $\left.q_{e 1}\right)$, and pseudo-second-order $\left(k_{2}, q_{e 2}\right.$, and $\left.h\right)$ kinetics models for AB80 adsorption at initial AB80 concentrations from 10 to $150 \mathrm{mg} \mathrm{L}^{-1}$, and temperatures from 25 to $60^{\circ} \mathrm{C}$, together with the corresponding $r^{2}$, RMSE, SSE, and 95\% confidence interval values.

The determination coefficients were higher with the pseudo-second-order model, and the RMSE and SSE values were lower than those obtained with the Elovich, fractional power, pseudo-first-order, and pseudo-second-order models, which denotes a good agreement of experimental data with the pseudo-second-order model for the initial AB80 concentrations and temperatures tested. Moreover, the equilibrium adsorption capacity $\left(q_{e 2}\right)$ values predicted by the pseudo-second-order kinetics model agree very well with the experimental data $\left(\exp q_{e}\right)$. Additionally, the pseudo-secondorder model successfully described the kinetics profiles of AB80 adsorption from aqueous solutions onto $\mathrm{Cu}-\mathrm{TiO}_{2}$ at the assayed initial AB80 concentrations and temperatures (continuous lines in Figures 4 and 5). According to these results, the $\mathrm{AB} 80$ adsorption kinetics on $\mathrm{Cu}-\mathrm{TiO} \mathrm{O}_{2}$ are best described by the pseudo-second-order model, which is based on the assumption that the rate-limiting step may be chemical sorption or chemisorption involving valence forces through the sharing or exchange of electrons between the adsorbent $\left(\mathrm{Cu}-\mathrm{TiO}_{2}\right)$ and sorbate $(\mathrm{AB} 80)$ [19]. This result is in agreement with that reported by Bourikas et al. [51], who proposed that the adsorption of sulfonic acid dyes on $\mathrm{TiO}_{2}$ occurs via the sulfonic group of the azo dye through the formation of a bidentate inner sphere surface complex.

The pseudo-second-order model is also the most suitable to describe the adsorption kinetics of reactive red 195 on $\mathrm{TiO}_{2}$ [19], C.I. basic blue 41 on N,F-codoped flower-like $\mathrm{TiO}_{2}$ [12], direct red 80 and acid green 25 on sodium alginate- $\mathrm{TiO}_{2}$ [42], and methylene blue on polypyrrole- $\mathrm{TiO}_{2}$ [45], among others.

Results also show that the pseudo-second-order model rate constant $\left(k_{2}\right)$ was strongly dependent on the initial AB80 concentration and temperature. The rate constant $k_{2}$ decreased as the initial AB80 concentration increased (Table 3), which may be observed because, at higher initial $\mathrm{AB} 80$ concentrations, the $\mathrm{Cu}-\mathrm{TiO}_{2}$ composite adsorbed larger amounts of $\mathrm{AB} 80$ and therefore required longer contact times to reach equilibrium. This trend has also been reported for other adsorption systems [19, 52, 53].
Furthermore, at the two initial AB80 concentrations assayed, $k_{2}$ values increased as the temperature of the adsorption system rose (Table 4). This can be explained on the basis of increases in the interactions between AB80 molecules and the $\mathrm{Cu}-\mathrm{TiO}_{2}$ composite with increasing temperature, which confirms that the $\mathrm{AB} 80$ adsorption rate is faster at higher temperatures, as well as confirming the endothermic nature of the adsorption process $[4,44]$.

Likewise, the initial adsorption rate $(h)$ tended to increase as the initial AB80 concentration (Table 3) and temperature (Table 4) increased, which confirms that the initial AB80 adsorption rate increased with the rise in initial dye concentration and temperature.

3.7. Adsorption Isotherm Modeling of AB80 onto $\mathrm{Cu}-\mathrm{TiO}_{2}$. Figure 6 presents the equilibrium isotherm for AB80 adsorption onto $\mathrm{Cu}-\mathrm{TiO}_{2}$ at $\mathrm{pH} 1.0$ and $25^{\circ} \mathrm{C}$. It is evident that the equilibrium adsorption capacity $\left(q_{e}\right)$ increased gradually with the increase in the equilibrium AB80 concentration $\left(C_{e}\right)$ until it reached a maximum constant value, of approximately $19.78 \mathrm{mg} \mathrm{g}^{-1}$. The shape of the AB80 adsorption isotherm indicates that as active adsorption sites of $\mathrm{Cu}-\mathrm{TiO}_{2}$ are occupied, it becomes more difficult for AB80 molecules to find available $\mathrm{Cu}-\mathrm{TiO}_{2}$ adsorption sites; that is, it suggests a progressive saturation of the $\mathrm{Cu}-\mathrm{TiO}_{2}$ composite [53].

The shape and initial slope of the AB80 adsorption isotherm belong to the type $\mathrm{L}$ isotherm of the Giles classification [54], which is generally associated with the adsorption of a monomolecular layer of adsorbate with a minimum competition for the solvent, a high affinity between adsorbate and adsorbent, and the occurrence of a chemisorption reaction between adsorbate and adsorbent [55].

In the present study, the experimental equilibrium data of $\mathrm{AB} 80$ adsorption onto $\mathrm{Cu}-\mathrm{TiO}_{2}$ were analyzed using two(Langmuir, Freundlich, Halsey, and Dubinin-Radushkevich), three- (Koble-Corrigan, Sips, Redlich-Peterson, Toth, and Khan), and four-parameter (Fritz-Schluender) isotherm models. Figure 6 shows the predicted fittings of the isotherm models to the experimental data, and Table 5 shows the model parameter values along with $95 \%$ confidence intervals, as well as $r^{2}$, SSE, and RMSE values.

The Langmuir model was found to have the best fit to the experimental data of AB80 adsorption among the twoparameter isotherm models, with a high determination coefficient $\left(r^{2}=0.994\right)$ and low RMSE (0.259) and SSE (0.203) values. In contrast, the Freundlich, Halsey, and DubininRadushkevich isotherm models were unable to describe the experimental equilibrium data, having lower coefficients of determination and higher RMSE and SSE values than those of the Langmuir model.

All of the three-parameter models (Koble-Corrigan, Sips, Redlich-Peterson, Toth, and Khan) as well as the fourparameter (Fritz-Schluender) model had high coefficients of determination and lower RMSE and SSE values. However, the $95 \%$ confidence intervals of the Koble-Corrigan, RedlichPeterson, Khan, and Fritz-Schluender isotherm parameters were wider than those of the Langmuir model. 
TABLE 5: Isotherm constants of two-, three-, and four-parameter models for $\mathrm{AB} 80$ adsorption onto $\mathrm{Cu}-\mathrm{TiO}_{2}$.

\begin{tabular}{|c|c|}
\hline \multicolumn{2}{|c|}{ Two-parameter models } \\
\hline \multicolumn{2}{|l|}{ Langmuir } \\
\hline$b\left[\mathrm{~L} \mathrm{mg}^{-1}\right]$ & $0.0465 \pm 0.009$ \\
\hline$q_{\max }\left[\mathrm{mg} \mathrm{g}^{-1}\right]$ & $22.23 \pm 1.87$ \\
\hline$r^{2}$ & 0.994 \\
\hline RMSE & 0.259 \\
\hline SSE & 0.203 \\
\hline \multicolumn{2}{|l|}{ Freundlich } \\
\hline$k_{f}\left[\mathrm{mg} \mathrm{g}^{-1}\right]\left[\mathrm{mg} \mathrm{L}^{-1}\right]^{-1 / n_{f}}$ & $3.038 \pm 1.971$ \\
\hline$n_{f}$ & $2.514 \pm 0.953$ \\
\hline$r^{2}$ & 0.931 \\
\hline RMSE & 1.71 \\
\hline SSE & 14.62 \\
\hline \multicolumn{2}{|l|}{ Halsey } \\
\hline$k_{H}\left[\mathrm{Lg}^{-1}\right]$ & $16.35 \pm 43.79$ \\
\hline$n_{H}$ & $2.514 \pm 0.953$ \\
\hline$r^{2}$ & 0.931 \\
\hline RMSE & 1.71 \\
\hline SSE & 14.62 \\
\hline \multicolumn{2}{|l|}{ Dubinin-Radushkevich } \\
\hline$B_{D}\left[\mathrm{~mol}^{2} \mathrm{~kJ}^{-2}\right]$ & 26.36 \\
\hline$q_{\max }\left[\mathrm{mg} \mathrm{g}^{-1}\right]$ & $18.14 \pm 6.23$ \\
\hline$r^{2}$ & 0.89 \\
\hline RMSE & 2.136 \\
\hline SSE & 22.81 \\
\hline \multicolumn{2}{|c|}{ Three-parameter models } \\
\hline \multicolumn{2}{|l|}{ Koble-Corrigan } \\
\hline$\alpha_{\mathrm{CK}}\left[\mathrm{L}^{n_{\mathrm{CK}}} \mathrm{mg}^{1-n_{\mathrm{CK}}} \mathrm{g}\right]$ & 1 \\
\hline$\beta_{\mathrm{CK}}\left[\mathrm{L} \mathrm{mg}^{-1}\right]^{n_{\mathrm{CK}}}$ & $0.041 \pm 0.05$ \\
\hline$n_{\mathrm{CK}}$ & $0.973 \pm 0.75$ \\
\hline$r^{2}$ & 0.992 \\
\hline RMSE & 0.589 \\
\hline SSE & 1.734 \\
\hline \multicolumn{2}{|l|}{ Sips } \\
\hline$b_{S}\left[\mathrm{mg} \mathrm{L}^{-1}\right]^{-1 / n_{S}}$ & $0.021 \pm 0.007$ \\
\hline$n_{S}$ & $0.9802 \pm 0.014$ \\
\hline$q_{\max }\left[\mathrm{mg} \mathrm{g}^{-1}\right]$ & $21.59 \pm 1.05$ \\
\hline$r^{2}$ & 0.998 \\
\hline RMSE & 0.205 \\
\hline SSE & 0.168 \\
\hline \multicolumn{2}{|l|}{ Redlich-Peterson } \\
\hline$a_{\mathrm{RP}}\left[\mathrm{L} \mathrm{mg}^{-1}\right]^{\beta_{\mathrm{RP}}}$ & $0.01223 \pm 0.013$ \\
\hline$\beta_{\mathrm{RP}}$ & $1.183 \pm 0.805$ \\
\hline$k_{\mathrm{RP}}\left[\mathrm{Lg}^{-1}\right]$ & $0.8462 \pm 0.579$ \\
\hline$r^{2}$ & 0.997 \\
\hline RMSE & 0.3163 \\
\hline SSE & 0.4002 \\
\hline \multicolumn{2}{|l|}{ Toth } \\
\hline$b_{T}\left[\mathrm{~L} \mathrm{mg}^{-1}\right]$ & 0.1 \\
\hline$n_{T}$ & $1.345 \pm 0.149$ \\
\hline$q_{\max }\left[\mathrm{mg} \mathrm{g}^{-1}\right]$ & $12.55 \pm 2.15$ \\
\hline$r^{2}$ & 0.9823 \\
\hline RMSE & 0.7904 \\
\hline SSE & 3.123 \\
\hline
\end{tabular}

TABLE 5: Continued.

\begin{tabular}{lc}
\hline Khan & \\
$b_{K}$ & $0.018 \pm 0.034$ \\
$a_{K}$ & $1.353 \pm 0.673$ \\
$q_{\max }\left[\mathrm{mg} \mathrm{g}^{-1}\right]$ & $42.65 \pm 39.88$ \\
$r^{2}$ & 0.996 \\
RMSE & 0.362 \\
SSE & 0.525 \\
\hline \multicolumn{2}{c}{ Four-parameter model } \\
Fritz-Schluender & \\
$A_{\mathrm{FS}}\left[\mathrm{mg} \mathrm{g}^{-1}\right]\left[\mathrm{mg} \mathrm{L}^{-1}\right]^{-\alpha_{\mathrm{FS}}}$ & $0.407 \pm 0.529$ \\
$B_{\mathrm{FS}}\left[\mathrm{mg} \mathrm{L}^{-1}\right]^{-\beta_{\mathrm{FS}}}$ & $0.0226 \pm 0.043$ \\
$\alpha_{\mathrm{FS}}$ & $1.336 \pm 1.666$ \\
$\beta_{\mathrm{FS}}$ & $1.302 \pm 0.452$ \\
$r^{2}$ & 0.999 \\
RMSE & 0.233 \\
SSE & 0.161 \\
\hline
\end{tabular}

These models were therefore not suitable to describe the experimental isotherm. Furthermore, the maximum AB80 adsorption capacities $\left(q_{\max }\right)$ predicted by the Toth and Khan models were substantially lower and higher, respectively, than that found experimentally $\left(19.78 \mathrm{mg} \mathrm{g}^{-1}\right)$, and consequently these isotherm models did not properly describe the adsorption equilibrium of $\mathrm{AB} 80$ by $\mathrm{Cu}-\mathrm{TiO}_{2}$. Moreover, the Sips model rendered a coefficient of determination, RMSE and SSE values, and 95\% confidence interval similar to those of the Langmuir model, and consequently neither the Langmuir model nor the Sips model showed any added advantage (Table 5). However, the exponent value of the Sips model was close to 1.0, with which value this isotherm model is reduced to the Langmuir model [4]. Based on these results, the Langmuir model agrees best with the experimental equilibrium data for the adsorption of $\mathrm{AB} 80$ by $\mathrm{Cu}-\mathrm{TiO}_{2}$. The applicability of the Langmuir model to the adsorption system under investigation suggests that the $\mathrm{AB} 80$ adsorption behavior of $\mathrm{Cu}-\mathrm{TiO}_{2}$ follows a homogeneous monolayer chemisorption process [56]. The Langmuir model also fitted the equilibrium data of $\mathrm{AB} 80$ adsorption by $\mathrm{TiO}_{2}$ [57].

The Langmuir model has great practical importance because it is simpler than the three- and four-parameter isotherm models and can consequently be applied and interpreted more easily and may therefore be especially useful for designing and scaling up adsorption processes [4].

The Langmuir model predicted a maximum AB80 adsorption capacity of $22.23 \mathrm{mgg}^{-1}$, which approximates the experimental $\mathrm{AB} 80$ adsorption capacity at equilibrium $\left(19.78 \mathrm{mg} \mathrm{g}^{-1}\right)$. The $\mathrm{AB} 80$ adsorption capacity of $\mathrm{Cu}-\mathrm{TiO}_{2}$ is similar to that reported for $\mathrm{TiO}_{2}$ at $\mathrm{pH} 6.0$ and higher than that found at $\mathrm{pH} 9.0$ [57].

Furthermore, the Langmuir equilibrium affinity constant (b) was $0.0465 \mathrm{~L} \mathrm{mg}^{-1}$ (Table 5), and this was used to calculate the dimensionless Hall separation factor $\left(R_{L}\right)$ and the surface coverage $(\theta)$, which are helpful to predict whether the adsorption system is "favorable" or "unfavorable" and to predict the fraction of $\mathrm{Cu}-\mathrm{TiO}_{2}$ adsorption sites occupied by $\mathrm{AB} 80$ molecules at equilibrium, respectively. Figure 7(a) shows that 


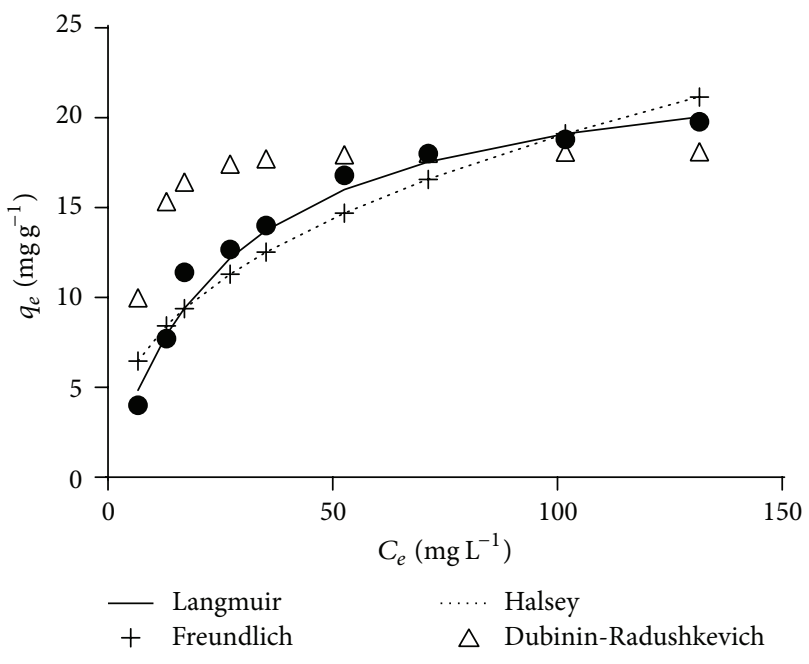

(a)

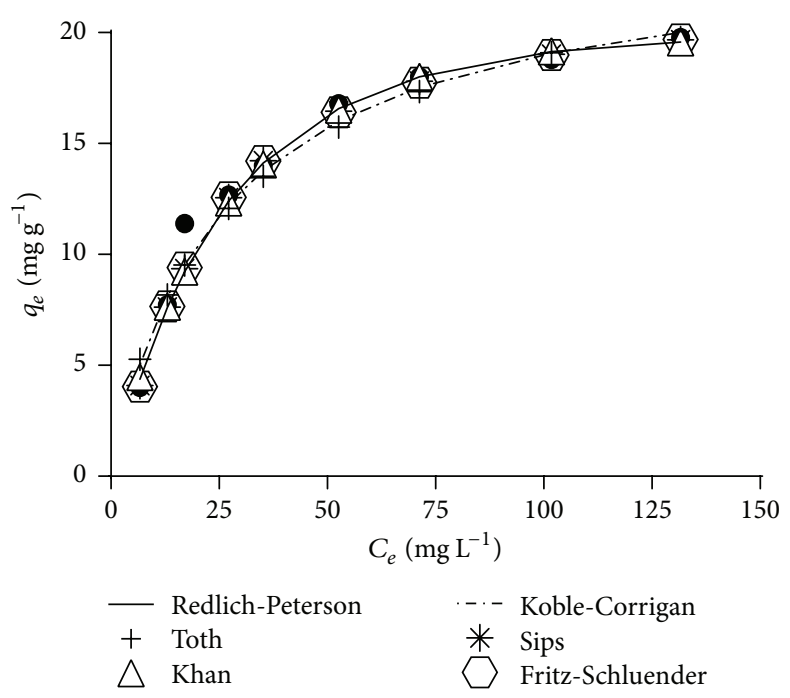

(b)

FIGURE 6: Experimental (๑) isotherm data and calculated isotherm data derived from two-parameter (a) and three- and four-parameter (b) models for $\mathrm{AB} 80$ adsorption by $\mathrm{Cu}-\mathrm{TiO}_{2}$.

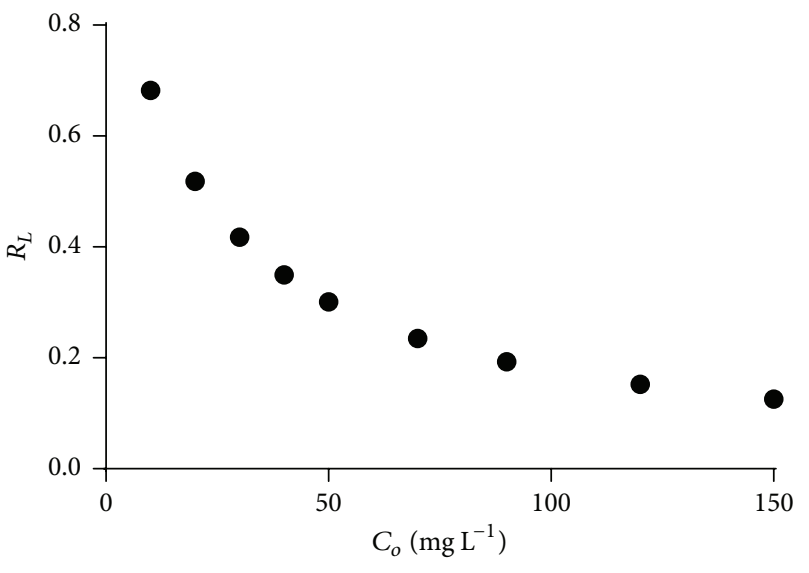

(a)

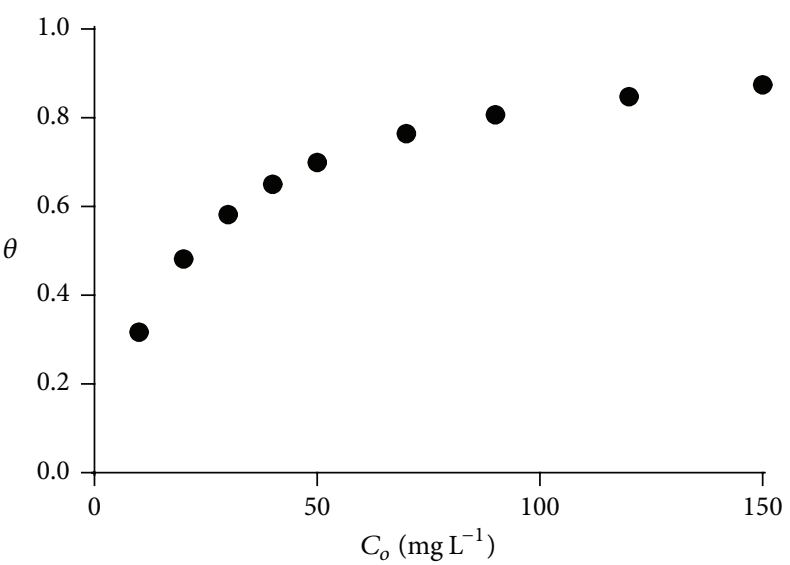

(b)

FIgURE 7: Dependence of separation factor (a) and surface coverage (b) on initial AB80 concentration.

the Hall separation factor decreased as the initial AB80 concentration increased, which indicates that $\mathrm{AB} 80$ adsorption is enhanced as the starting concentration of the dye in solution increases. Furthermore, all $R_{L}$ values obtained were between 0 and 1.0, indicating that the $\mathrm{AB} 80$ adsorption by $\mathrm{Cu}-\mathrm{TiO}_{2}$ was favorable. Figure 7(b) shows that the surface coverage tends to approach unity with an increase in initial $A B 80$ concentration, which indicates that the $\mathrm{Cu}-\mathrm{TiO}_{2}$ surface was almost completely covered with a monomolecular layer of AB80 molecules at the higher AB80 concentrations.

To the best of our knowledge, no previous research has been reported on $\mathrm{AB} 80$ adsorption by doped $\mathrm{TiO}_{2}$.

3.8. AB80 Adsorption Thermodynamics. Thermodynamic studies for the present adsorption of $\mathrm{AB} 80$ onto $\mathrm{Cu}-\mathrm{TiO}_{2}$ were undertaken to elucidate the mechanism involved in and the feasibility of the AB80 adsorption process. Different relevant thermodynamic parameters, such as the Arrhenius activation energy $\left(E_{A}\right)$, activation enthalpy change $\left(\Delta H^{*}\right)$, activation entropy change $\left(\Delta S^{*}\right)$, and free energy change $\left(\Delta G^{*}\right)$, were estimated, and the results are reported in Table 6.

The values of $E_{A}$ were found to be 12.75 and $24.32 \mathrm{~kJ} \mathrm{~mol}^{-1}$ when initial $A B 80$ concentrations of 30 and $120 \mathrm{mg} \mathrm{L}^{-1}$ were used, respectively. The magnitude of $E_{A}$ is commonly used to obtain information regarding whether the adsorption process is physical (physisorption) or chemical (chemisorption). $E_{A}$ value for physical adsorption is usually not higher than $4.184 \mathrm{~kJ} \mathrm{~mol}^{-1}$, whereas for chemical adsorption it is between 8.4 and $83.7 \mathrm{~kJ} \mathrm{~mol}^{-1}$ [50]. Therefore, $\mathrm{Cu}-\mathrm{TiO}_{2}$ adsorbs $\mathrm{AB} 80$ molecules by a chemical adsorption reaction, which agrees with the results of the kinetics and isotherm experiments described above.

$\Delta H^{*}$ values were positive $\left(10.17\right.$ and $\left.21.71 \mathrm{~kJ} \mathrm{~mol}^{-1}\right)$ at the two initial AB80 concentrations tested $\left(30\right.$ and $\left.120 \mathrm{mg} \mathrm{L}^{-1}\right)$, 
TABLE 6: Thermodynamic parameters for the adsorption of $\mathrm{AB} 80$ onto $\mathrm{Cu}-\mathrm{TiO}_{2}$.

\begin{tabular}{|c|c|c|c|c|c|c|}
\hline $\begin{array}{l}C_{0} \\
{\left[\mathrm{mg} \mathrm{L}^{-1}\right]}\end{array}$ & $\begin{array}{c}T \\
{\left[{ }^{\circ} \mathrm{C}\right]}\end{array}$ & $\begin{array}{c}\Delta G^{*} \\
{\left[\mathrm{~kJ} \mathrm{~mol}^{-1}\right]}\end{array}$ & $\begin{array}{c}E_{A} \\
{\left[\mathrm{~kJ} \mathrm{~mol}^{-1}\right]}\end{array}$ & $\begin{array}{c}A_{0} \\
{\left[\mathrm{~g} \mathrm{mg}^{-1} \mathrm{~min}^{-1}\right]}\end{array}$ & $\begin{array}{c}\Delta S^{*} \\
{\left[\mathrm{~kJ} \mathrm{~mol}^{-1} \mathrm{~K}^{-1}\right]}\end{array}$ & $\begin{array}{c}\Delta H^{*} \\
{\left[\mathrm{~kJ} \mathrm{~mol}^{-1}\right]}\end{array}$ \\
\hline \multirow{4}{*}{30} & 25 & 28.036 & \multirow{4}{*}{12.75} & \multirow{4}{*}{1.30} & \multirow{4}{*}{-0.06} & \multirow{4}{*}{10.17} \\
\hline & 40 & 28.935 & & & & \\
\hline & 50 & 29.534 & & & & \\
\hline & 60 & 30.133 & & & & \\
\hline \multirow{4}{*}{120} & 25 & 29.879 & \multirow{4}{*}{24.32} & \multirow{4}{*}{65.67} & \multirow{4}{*}{-0.027} & \multirow{4}{*}{21.71} \\
\hline & 40 & 30.291 & & & & \\
\hline & 50 & 30.565 & & & & \\
\hline & 60 & 30.839 & & & & \\
\hline
\end{tabular}

which further confirms that the $\mathrm{AB} 80$ adsorption reaction is endothermic. The values of $\Delta S^{*}$ were -0.06 and $-0.027 \mathrm{~kJ} \mathrm{~mol}^{-1} \mathrm{~K}^{-1}$ at initial AB80 concentrations of 30 and $120 \mathrm{mg} \mathrm{L}^{-1}$, respectively. The negative $\Delta S^{*}$ values indicate the association of $\mathrm{AB} 80$ molecules with active $\mathrm{Cu}-\mathrm{TiO}_{2}$ sites, which leads to the formation of a stable chemical complex on the $\mathrm{Cu}-\mathrm{TiO}_{2}$ surface. These values also indicate that no significant change occurs in the internal structure of the adsorbent during the adsorption process $[30,58]$. This also confirmed the affinity of $\mathrm{Cu}-\mathrm{TiO}_{2}$ for $\mathrm{AB} 80$ [39].

Moreover, at all assayed initial AB80 concentrations and temperatures, $\Delta G^{*}$ values were positive (28.04$30.84 \mathrm{~kJ} \mathrm{~mol}^{-1}$ ), which indicated that the adsorption process of $\mathrm{AB} 80$ onto the active adsorption sites offered by $\mathrm{Cu}-\mathrm{TiO}_{2}$ was not spontaneous in nature and therefore needs to be driven by an outside source of energy [4].

\section{Conclusions}

$\mathrm{A} \mathrm{Cu}-\mathrm{TiO}_{2}$ photocatalyst was synthesized and characterized by X-ray diffraction (XRD), field emission scanning electron microscopy (FE-SEM), energy dispersive X-ray spectroscopy (EDS), and UV-Vis scanning spectroscopy, as well as in terms of specific surface area and pore size distribution; in addition, its ability to remove $\mathrm{AB} 80$ from aqueous solutions by adsorption was investigated.

It was found that the modification of $\mathrm{TiO}_{2}$ with $\mathrm{Cu}$ reduced the energy of band gap from 3.18 to $2.3 \mathrm{eV}$. Both anatase and rutile phases are present in the $\mathrm{Cu}-\mathrm{TiO}_{2}$ composite and the $\mathrm{Cu}$ content of this composite is high.

The adsorptive removal of $\mathrm{AB} 80$ by $\mathrm{Cu}-\mathrm{TiO}_{2}$ was found to be strongly dependent on the solution $\mathrm{pH}$, initial $\mathrm{AB} 80$ concentration, contact time, and temperature. The adsorption behaviors of $\mathrm{AB} 80$ on $\mathrm{Cu}-\mathrm{TiO}_{2}$ were described best with the pseudo-second-order kinetics model and the Langmuir isotherm model. Thermodynamic parameters confirmed the endothermic and nonspontaneous nature of the AB80 adsorption process.

\section{Conflict of Interests}

The authors declare that there is no conflict of interests regarding the publication of this paper.

\section{Acknowledgments}

The authors gratefully acknowledge the support provided by the scientific staff of the Central Laboratories of Spectroscopy, and Biotechnology and Molecular Biology at ENCB-IPN, as well as the financial support provided by the Secretaría de Investigación y Posgrado, IPN, Mexico, and the Pontificia Universidad Javeriana (Research Project 6272), Bogota, Colombia. The CONACyT awarded a graduate scholarship to one of the coauthors (Ingrid Johanna Puentes-Cárdenas). Eliseo Cristiani-Urbina is a holder of grants from COFAAIPN, EDI-IPN, and SNI-CONACyT.

\section{References}

[1] P. Sharma, H. Kaur, M. Sharma, and V. Sahore, "A review on applicability of naturally available adsorbents for the removal of hazardous dyes from aqueous waste," Environmental Monitoring and Assessment, vol. 183, no. 1-4, pp. 151-195, 2011.

[2] Y. Du, M. Pei, Y. He, F. Yu, W. Guo, and L. Wang, "Preparation, characterization and application of magnetic $\mathrm{Fe}_{3} \mathrm{O}_{4}$-CS for the adsorption of orange I from aqueous solutions," PLOS ONE, vol. 9, no. 10, Article ID e108647, 2014.

[3] I. Guerrero-Coronilla, L. Morales-Barrera, T. L. VillegasGarrido, and E. Cristiani-Urbina, "Biosorption of amaranth dye from aqueous solution by roots, leaves, stems and the whole plant of Eichhornia crassipes," Environmental Engineering and Management Journal, vol. 13, no. 8, pp. 1917-1926, 2014.

[4] I. Guerrero-Coronilla, L. Morales-Barrera, and E. CristianiUrbina, "Kinetic, isotherm and thermodynamic studies of amaranth dye biosorption from aqueous solution onto water hyacinth leaves," Journal of Environmental Management, vol. 152, pp. 99-108, 2015.

[5] A. Srinivasan and T. Viraraghavan, "Decolorization of dye wastewaters by biosorbents: a review," Journal of Environmental Management, vol. 91, no. 10, pp. 1915-1929, 2010.

[6] A. Bhatnagar and A. K. Minocha, "Assessment of the biosorption characteristics of lychee (Litchi chinensis) peel waste for the removal of acid blue 25 dye from water," Environmental Technology, vol. 31, no. 1, pp. 97-105, 2010.

[7] W. Li, D. Li, Z. Chen et al., "High-efficient degradation of dyes by $\mathrm{ZnCdS}$ solid solutions under visible irradiation," The Journal of Physical Chemistry C, vol. 38, pp. 14943-14947, 2008.

[8] T. Pauporté and J. Rathouský, "Electrodeposited mesoporous $\mathrm{ZnO}$ thin films as efficient photocatalysts for the degradation 
of dye pollutants," Journal of Physical Chemistry C, vol. 111, no. 21, pp. 7639-7644, 2007.

[9] R. Jain, M. Mathur, S. Sikarwar, and A. Mittal, "Removal of the hazardous dye rhodamine B through photocatalytic and adsorption treatments," Journal of Environmental Management, vol. 85, no. 4, pp. 956-964, 2007.

[10] J. Marugán, M. López-Muñoz, R. van Grieken, and J. Aguado, "Photocatalytic decolorization and mineralization of dyes with nanocrystalline $\mathrm{TiO}_{2} / \mathrm{SiO}_{2}$ materials," Industrial \& Engineering Chemistry Research, vol. 46, no. 23, pp. 7605-7610, 2007.

[11] L. G. Devi and S. G. Kumar, "Exploring the critical dependence of adsorption of various dyes on the degradation rate using $\mathrm{Ln}^{3+}-\mathrm{TiO}_{2}$ surface under UV/solar light," Applied Surface Science, vol. 261, pp. 137-146, 2012.

[12] Y. Jiang, Y. Luo, F. Zhang, L. Guo, and L. Ni, "Equilibrium and kinetic studies of C.I. Basic blue 41 adsorption onto N, Fcodoped flower-like $\mathrm{TiO}_{2}$ microspheres," Applied Surface Science, vol. 273, pp. 448-456, 2013.

[13] C. H. Liang, F. B. Li, C. S. Liu, J. L. Lü, and X. G. Wang, "The enhancement of adsorption and photocatalytic activity of rare earth ions doped $\mathrm{TiO}_{2}$ for the degradation of Orange I," Dyes and Pigments, vol. 76, no. 2, pp. 477-484, 2008.

[14] J. Araña, C. G. Rodríguez, O. G. Díaz, J. A. H. Melián, and J. P. Peña, "Role of $\mathrm{Cu}$ in the $\mathrm{Cu}-\mathrm{TiO}_{2}$ photocatalytic degradation of dihydroxybenzenes," Catalysis Today, vol. 101, no. 3-4, pp. 261266, 2005.

[15] H. W. P. Carvalho, A. P. L. Batista, P. Hammer, and T. C. Ramalho, "Photocatalytic degradation of methylene blue by $\mathrm{TiO}_{2}$-Cu thin films: theoretical and experimental study," Journal of Hazardous Materials, vol. 184, no. 1-3, pp. 273-280, 2010.

[16] P. Muthirulan, C. Nirmala Devi, and M. Meenakshi Sundaram, "Synchronous role of coupled adsorption and photocatalytic degradation on $\mathrm{CAC}-\mathrm{TiO}_{2}$ composite generating excellent mineralization of alizarin cyanine green dye in aqueous solution," Arabian Journal of Chemistry, 2013.

[17] G. Chen and J. Hou, "Photocatalytical elimination of alizarin red by chitosan-Cds composite nanoparticles," Environmental Science, vol. 2, no. 1, pp. 56-62, 2007.

[18] J. Zhao, T. Wu, K. Wu, K. Oikawa, H. Hidaka, and N. Serpone, "Photoassisted degradation of dye pollutants. 3. Degradation of the cationic dye rhodamine B in aqueous anionic surfactant/ $\mathrm{TiO}_{2}$ dispersions under visible light irradiation: evidence for the need of substrate adsorption on $\mathrm{TiO}_{2}$ particles," Environmental Science \& Technology, vol. 32, no. 16, pp. 2394-2400, 1998.

[19] V. Belessi, G. Romanos, N. Boukos, D. Lambropoulou, and C. Trapalis, "Removal of reactive red 195 from aqueous solutions by adsorption on the surface of $\mathrm{TiO}_{2}$ nanoparticles," Journal of Hazardous Materials, vol. 170, no. 2-3, pp. 836-844, 2009.

[20] E. Kordouli, K. Bourikas, A. Lycourghiotis, and C. Kordulis, "The mechanism of azo-dyes adsorption on the titanium dioxide surface and their photocatalytic degradation over samples with various anatase/rutile ratios," Catalysis Today, vol. 252, pp. 128-135, 2015.

[21] Environment Canada and Health Canada, "Screening assessment for the challenge benzenesulfonic acid, 3,3' - [(9,10-dihydro-9,10-dioxo-1,4-anthracenediyl)diimino]bis [2,4,6trimethyl-, disodium salt] (acid blue 80)," Chemical Abstracts Service Registry 4474-24-2, Environment Canada and Health, 2008, http://www.ec.gc.ca/ese-ees/default.asp?lang=En\&n= 69053600-1.
[22] N. R. Mathews, E. R. Morales, M. A. Cortés-Jacome, and J. A. Toledo Antonio, " $\mathrm{TiO}_{2}$ thin films-influence of annealing temperature on structural, optical and photocatalytic properties," Solar Energy, vol. 83, no. 9, pp. 1499-1508, 2009.

[23] Y. Pihosh, M. Goto, A. Kasahara, and M. Tosa, "Photocatalytic property of $\mathrm{TiO}_{2}$ thin films sputtered-deposited on unheated substrates," Applied Surface Science, vol. 256, no. 4, pp. 937-942, 2009.

[24] S. H. Hasan, D. Ranjan, and M. Talat, "Water hyacinth biomass (WHB) for the biosorption of hexavalent chromium: optimization of process parameters," BioResources, vol. 5, no. 2, pp. 563$575,2010$.

[25] S. Basha and Z. V. P. Murthy, "Kinetic and equilibrium models for biosorption of $\mathrm{Cr}(\mathrm{VI})$ on chemically modified seaweed, Cystoseira indica," Process Biochemistry, vol. 42, no. 11, pp. 15211529, 2007.

[26] Y.-S. Ho, "Review of second-order models for adsorption systems," Journal of Hazardous Materials, vol. 136, no. 3, pp. 681689, 2006.

[27] J. Febrianto, A. N. Kosasih, J. Sunarso, Y.-H. Ju, N. Indraswati, and S. Ismadji, "Equilibrium and kinetic studies in adsorption of heavy metals using biosorbent: a summary of recent studies," Journal of Hazardous Materials, vol. 162, no. 2-3, pp. 616-645, 2009.

[28] M. A. Hanif, R. Nadeem, H. N. Bhatti, N. R. Ahmad, and T. M. Ansari, "Ni(II) biosorption by Cassia fistula (Golden Shower) biomass," Journal of Hazardous Materials B, vol. 139, no. 2, pp. 345-355, 2007.

[29] S. Basha, Z. V. P. Murthy, and B. Jha, "Sorption of Hg(II) from aqueous solutions onto Carica papaya: application of isotherms," Industrial \& Engineering Chemistry Research, vol. 47, no. 3, pp. 980-986, 2008.

[30] M. Doğan, H. Abak, and M. Alkan, "Adsorption of methylene blue onto hazelnut shell: kinetics, mechanism and activation parameters," Journal of Hazardous Materials, vol. 164, no. 1, pp. 172-181, 2009.

[31] J. B. Condon, Ed., Measurements and Theory, Elsevier, The Netherlands, 1st edition, 2006.

[32] C. Villanueva-Jaramillo, A. K. Carrascal-Camacho, M. C. Campos Pinilla, J. C. Salcedo-Reyes, A. E. Florido-Cuellar, and A. M. Pedroza-Rodríguez, "Inactivation of Escherichia coli in domestic wastewater using $\mathrm{TiO}_{2} / \mathrm{Cu}$ thin films illuminated with white light," in Proceedings of the 19th International Conference in Photochemical Conversion and Storage of Solar Energy, Pasadena, Calif, USA, July-August 2012.

[33] A. Hernández, A. K. Carrascal, C. E. Daza, and A. M. Pedroza, " $\mathrm{Cu}$-modified $\mathrm{TiO}_{2}$-photocatalysis for Salmonella spp inactivation," in Proceedings of the 19th International Conference in Photochemical Conversion and Storage of Solar Energy, Pasadena, Calif, USA, 2012.

[34] C. Karunakaran, G. Abiramasundari, P. Gomathisankar, G. Manikandan, and V. Anandi, "Cu-doped $\mathrm{TiO}_{2}$ nanoparticles for photocatalytic disinfection of bacteria under visible light," Journal of Colloid and Interface Science, vol. 352, no. 1, pp. 6874, 2010.

[35] W. Li, R. Liang, A. Hu, Z. Huang, and Y. N. Zhou, "Generation of oxygen vacancies in visible light activated one-dimensional iodine $\mathrm{TiO}_{2}$ photocatalysts," RSC Advances, vol. 4, no. 70, pp. 36959-36966, 2014. 
[36] X. Yang, S. Wang, H. Sun, X. Wang, and J. Lian, "Preparation and photocatalytic performance of $\mathrm{Cu}$-doped $\mathrm{TiO}_{2}$ nanoparticles," Transactions of Nonferrous Metals Society of China, vol. 25, no. 2, pp. 504-509, 2015.

[37] D. L. Liao, G. S. Wu, and B. Q. Liao, "Zeta potential of shapecontrolled $\mathrm{TiO}_{2}$ nanoparticles with surfactants," Colloids and Surfaces A: Physicochemical and Engineering Aspects, vol. 348, no. 1-3, pp. 270-275, 2009.

[38] I. S. Grover, S. Singh, and B. Pal, “The preparation, surface structure, zeta potential, surface charge density and photocatalytic activity of $\mathrm{TiO}_{2}$ nanostructures of different shapes," Applied Surface Science, vol. 280, pp. 366-372, 2013.

[39] R. K. Gautam, A. Mudhoo, and M. C. Chattopadhyaya, "Kinetic, equilibrium, thermodynamic studies and spectroscopic analysis of alizarin red S removal by mustard husk," Journal of Environmental Chemical Engineering, vol. 1, no. 4, pp. 1283-1291, 2013.

[40] A. S. Franca, L. S. Oliveira, V. F. Oliveira, and C. C. O. Alves, "Potential use of Crambe abyssinica press cake as an adsorbent: batch and continuous studies," Environmental Engineering and Management Journal, vol. 13, pp. 3025-3036, 2014.

[41] S. Dutta, S. A. Parsons, C. Bhattacharjee, P. Jarvis, S. Datta, and S. Bandyopadhyay, "Kinetic study of adsorption and photodecolorization of reactive red 198 on $\mathrm{TiO}_{2}$ surface," Chemical Engineering Journal, vol. 155, no. 3, pp. 674-679, 2009.

[42] N. M. Mahmoodi, B. Hayati, M. Arami, and H. Bahrami, "Preparation, characterization and dye adsorption properties of biocompatible composite (alginate/titania nanoparticle)," Desalination, vol. 275, no. 1-3, pp. 93-101, 2011.

[43] K.-J. Hwang, S.-H. Jung, D.-W. Park, S.-J. Yoo, and J.-W. Lee, "Heterogeneous ruthenium dye adsorption on nano-structured $\mathrm{TiO}_{2}$ films for dye-sensitized solar cells," Current Applied Physics, vol. 10, pp. S184-S187, 2010.

[44] I. J. Puentes-Cárdenas, A. M. Pedroza-Rodríguez, M. Navarrete-López, T. L. Villegas-Garrido, and E. CristianiUrbina, "Biosorption of trivalent chromium from aqueous solutions by Pleurotus ostreatus biomass," Environmental Engineering and Management Journal, vol. 11, no. 10, pp. 1741-1752, 2012.

[45] J. Li, J. Feng, and W. Yan, "Excellent adsorption and desorption characteristics of polypyrrole/ $\mathrm{TiO}_{2}$ composite for methylene blue," Applied Surface Science, vol. 279, pp. 400-408, 2013.

[46] D. El-Mekkawi and H. R. Galal, "Removal of a synthetic dye 'Direct Fast Blue B2RL' via adsorption and photocatalytic degradation using low cost rutile and Degussa P25 titanium dioxide," Journal of Hydro-Environment Research, vol. 7, no. 3, pp. 219-226, 2013.

[47] T.-Y. Kim, J.-W. Lee, E.-M. Jin, J.-Y. Park, J.-H. Kim, and K.-H. Park, "In situ measurement of dye adsorption on $\mathrm{TiO}_{2}$ thin films for dye-sensitized solar cells," Measurement, vol. 46, no. 5, pp. 1692-1697, 2013.

[48] M. L. Yola, T. Eren, N. Atar, and S. Wang, "Adsorptive and photocatalytic removal of reactive dyes by silver nanoparticlecolemanite ore waste," Chemical Engineering Journal, vol. 242, pp. 333-340, 2013.

[49] A. Çelekli, G. Ílgün, and H. Bozkurt, "Sorption equilibrium, kinetic, thermodynamic, and desorption studies of reactive red 120 on Chara contraria," Chemical Engineering Journal, vol. 191, pp. 228-235, 2012.

[50] J. G. Flores-Garnica, L. Morales-Barrera, G. Pineda-Camacho, and E. Cristiani-Urbina, "Biosorption of $\mathrm{Ni}(\mathrm{II})$ from aqueous solutions by Litchi chinensis seeds," Bioresource Technology, vol. 136, pp. 635-643, 2013.
[51] K. Bourikas, M. Stylidi, D. I. Kondarides, and X. E. Verykios, "Adsorption of Acid Orange 7 on the surface of titanium dioxide," Langmuir, vol. 21, no. 20, pp. 9222-9230, 2005.

[52] W. Plazinski, W. Rudzinski, and A. Plazinska, "Theoretical models of sorption kinetics including a surface reaction mechanism: a review," Advances in Colloid and Interface Science, vol. 152, no. 1-2, pp. 2-13, 2009.

[53] A. Hernández-Estévez and E. Cristiani-Urbina, "Nickel(II) biosorption from aqueous solutions by shrimp head biomass," Environmental Monitoring and Assessment, vol. 186, no. 11, pp. 7987-7998, 2014.

[54] C. H. Giles, D. Smith, and A. Huitson, "A general treatment and classification of the solute adsorption isotherm. I. Theoretical," Journal of Colloid And Interface Science, vol. 47, no. 3, pp. 755765, 1974.

[55] G. Limousin, J.-P. Gaudet, L. Charlet, S. Szenknect, V. Barthès, and M. Krimissa, "Sorption isotherms: a review on physical bases, modeling and measurement," Applied Geochemistry, vol. 22, no. 2, pp. 249-275, 2007.

[56] H. Yan, H. Li, H. Yang, A. Li, and R. Cheng, "Removal of various cationic dyes from aqueous solutions using a kind of fully biodegradable magnetic composite microsphere," Chemical Engineering Journal, vol. 223, pp. 402-411, 2013.

[57] Y. Su, L. Deng, N. Zhang, X. Wang, and X. Zhu, "Photocatalytic degradation of C.I. Acid Blue 80 in aqueous suspensions of titanium dioxide under sunlight," Reaction Kinetics and Catalysis Letters, vol. 98, no. 2, pp. 227-240, 2009.

[58] N. Ben-Tal, B. Honig, C. K. Bagdassarian, and A. Ben-Shaul, "Association entropy in adsorption processes," Biophysical Journal, vol. 79, no. 3, pp. 1180-1187, 2000. 

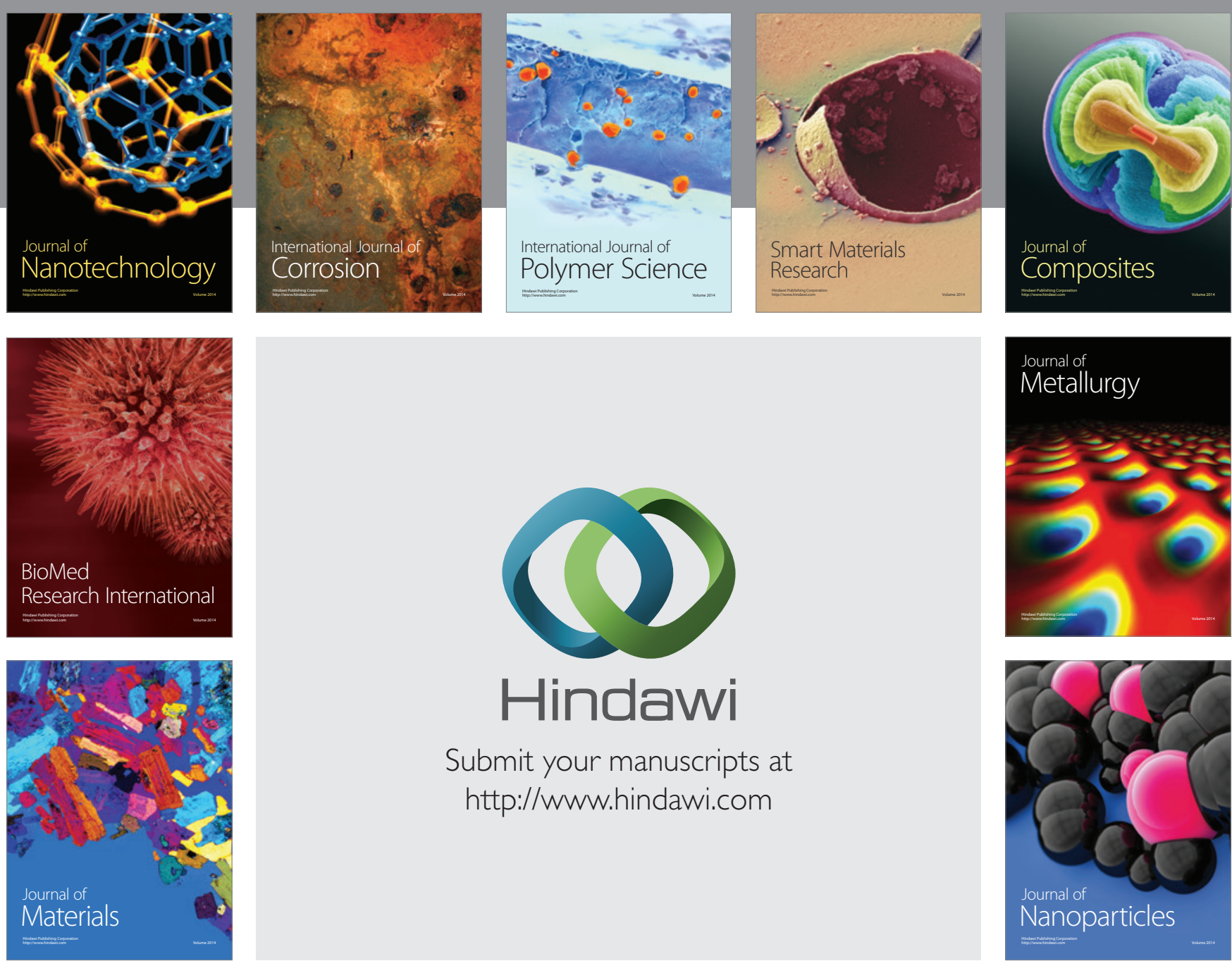

\section{Hindawi}

Submit your manuscripts at

http://www.hindawi.com

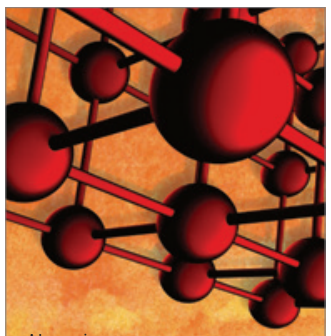

Materials Science and Engineering
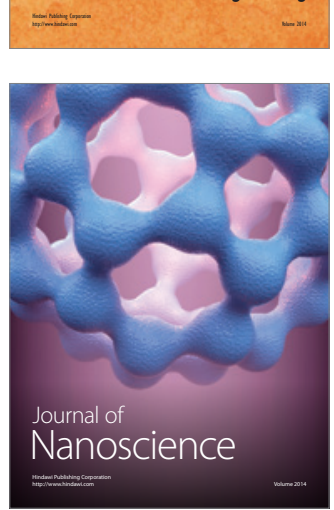
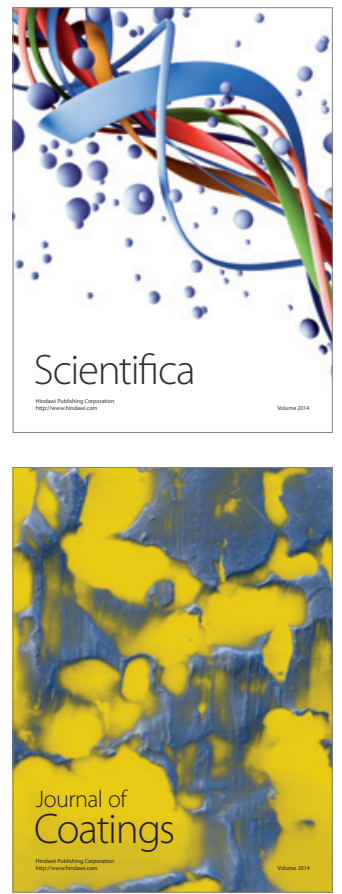
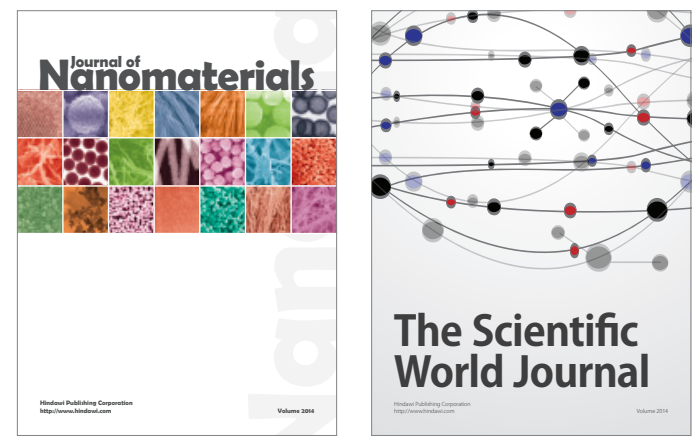

The Scientific World Journal
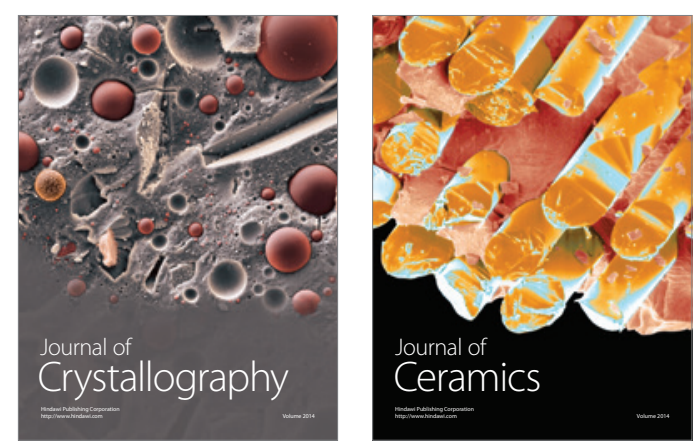
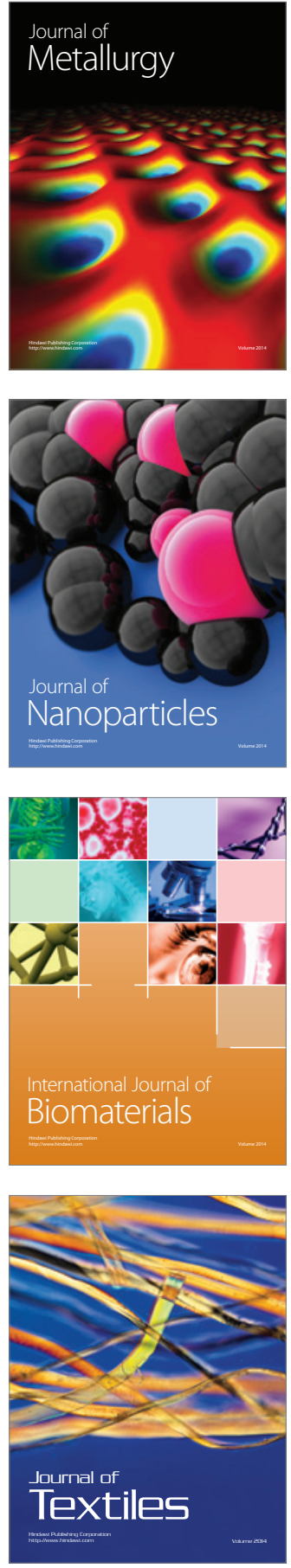